\title{
Detection of complement activation using monoclonal antibodies against C3d
}

\author{
Joshua M. Thurman, ${ }^{1}$ Liudmila Kulik, ${ }^{1}$ Heather Orth,, ${ }^{1}$ Maria Wong, ${ }^{1}$ Brandon Renner, ${ }^{1}$ \\ Siranush A. Sargsyan, ${ }^{1}$ Lynne M. Mitchell, ${ }^{2}$ Dennis E. Hourcade, ${ }^{2}$ Jonathan P. Hannan, ${ }^{1}$ \\ James M. Kovacs, ${ }^{1}$ Beth Coughlin, ${ }^{3}$ Alex S. Woodell, ${ }^{4}$ Matthew C. Pickering, ${ }^{5}$ \\ Bärbel Rohrer, ${ }^{3,4,6}$ and V. Michael Holers ${ }^{1}$ \\ 1Department of Medicine, University of Colorado School of Medicine, Aurora, Colorado, USA. 2Department of Medicine, Division of Rheumatology, \\ Washington University School of Medicine, St. Louis, Missouri, USA. ${ }^{3}$ Department of Ophthalmology, Medical University of South Carolina, \\ Charleston, South Carolina, USA. ${ }^{4}$ Research Service 151, Ralph H. Johnson VA Medical Center, Charleston, South Carolina, USA. \\ ${ }^{5}$ Centre for Complement and Inflammation Research, Imperial College, United Kingdom. ${ }^{6}$ Department of Neurosciences, \\ Division of Research, Medical University of South Carolina, Charleston, South Carolina, USA.
}

\begin{abstract}
During complement activation the $\mathrm{C} 3$ protein is cleaved, and $\mathrm{C} 3$ activation fragments are covalently fixed to tissues. Tissue-bound C3 fragments are a durable biomarker of tissue inflammation, and these fragments have been exploited as addressable binding ligands for targeted therapeutics and diagnostic agents. We have generated cross-reactive murine monoclonal antibodies against human and mouse C3d, the final C3 degradation fragment generated during complement activation. We developed 3 monoclonal antibodies $(3 \mathrm{~d} 8 \mathrm{~b}, 3 \mathrm{~d} 9 \mathrm{a}$, and 3d29) that preferentially bind to the $\mathrm{iC} 3 \mathrm{~b}, \mathrm{C3dg}$, and C3d fragments in solution, but do not bind to intact $\mathrm{C} 3$ or C3b. The same 3 clones also bind to tissue-bound $\mathrm{C} 3$ activation fragments when injected systemically. Using mouse models of renal and ocular disease, we confirmed that, following systemic injection, the antibodies accumulated at sites of $\mathrm{C} 3$ fragment deposition within the glomerulus, the renal tubulointerstitium, and the posterior pole of the eye. To detect antibodies bound within the eye, we used optical imaging and observed accumulation of the antibodies within retinal lesions in a model of choroidal neovascularization (CNV). Our results demonstrate that imaging methods that use these antibodies may provide a sensitive means of detecting and monitoring complement activation-associated tissue inflammation.
\end{abstract}

\section{Introduction}

The complement system is an important arm of the innate immune system, providing critical protection against invasive pathogens (1) and contributing to the pathogenesis of numerous autoimmune and inflammatory diseases (2). During the course of complement activation, the $\mathrm{C} 3$ protein undergoes proteolytic cleavage at several different sites (Figure 1). The cleavage fragments are fixed to nearby tissues through a covalent linkage originating from the thioester site on $\mathrm{C} 3$ with hydroxyl or primary amine groups on acceptor surfaces (3-5). Thus, the deposition of C3 fragments on tissue surfaces constitutes a durable signal of tissue inflammation. For this reason, tissue-bound C3 fragments are commonly used clinically and experimentally as biomarkers of immune activation. Renal biopsies from patients with glomerulonephritis, for example, are routinely immunostained for C3 fragments, and the detection of glomerular C3 fragments serves as a sensitive and robust indicator of disease activity (6). C3 deposition has also been recognized to occur in all stages of age-related macular degeneration (7).

Because tissue-bound C3 fragments are associated with local inflammation, they have also been exploited as addressable binding ligands for targeted therapeutics and diagnostic agents in several tissues, including the kidneys, the heart, the brain, and the eyes (8-12). These targeted agents have employed recombinant forms of complement receptor 2 (CR2), a protein that can discriminate

Conflict of interest: Joshua M. Thurman and V. Michael Holers are paid consultants for Alexion Pharmaceuticals, Inc. A patent application has been filed for the monoclonal antibodies described in this manuscript.

Citation for this article: J Clin Invest. 2013;123(5):2218-2230. doi:10.1172/JCI65861. between intact C3 in the plasma and tissue-bound C3 fragments. The rationale for this approach is that systemically administered agents can be delivered to sites of inflammation through their affinity with the iC $3 \mathrm{~b}$ and $\mathrm{C} 3 \mathrm{~d}$ fragments. By directing therapeutic agents to molecular targets, one can achieve a high degree of local activity with the drug while minimizing its systemic side effects (13). We have also used a CR2-targeted contrast agent to detect tissue-bound C3 fragments and renal disease activity by MRI ( 9 , 10). Although specific for the cleaved forms of C3, CR2-targeted agents probably bind these fragments with a relatively low affinity (reported values range from 1 to $10 \mu \mathrm{M}$ at physiologic ionic strength) (14-16). Higher-affinity targeting vectors for epitopes on the cleaved forms of $\mathrm{C} 3$ could potentially deliver therapeutic and diagnostic agents to sites of inflammation with even greater efficiency, durability, and specificity.

Informative monoclonal antibodies ( $\mathrm{mAbs}$ ) against tissue-bound C3 fragments have many biomedical applications. They could be used as in vivo delivery vehicles for new therapeutic and diagnostic agents. They could also potentially modulate the biologic functions of the C3 fragments. Such antibodies could also be useful for identifying specific C3 fragments (e.g., C3b, iC3b, C3dg, and C3d) and quantifying their relative abundance. There are, however, several barriers to the generation of such antibodies by standard methods. Like CR2, the antibodies must recognize epitopes of cleaved $\mathrm{C} 3$ that are not exposed on intact C3 (which circulates at a concentration of 1 to $2 \mathrm{mg} / \mathrm{ml}$ ). This is feasible, however, since internal regions of $\mathrm{C} 3 \mathrm{~d}$ (and also $\mathrm{iC} 3 \mathrm{~b}$ and $\mathrm{C} 3 \mathrm{dg}$ ) are exposed by conformational changes in $\mathrm{C} 3$ during its activation and subsequent proteolytic processing of its fragments (17). Another difficulty is that standard methods for generating and cloning hybridomas may 


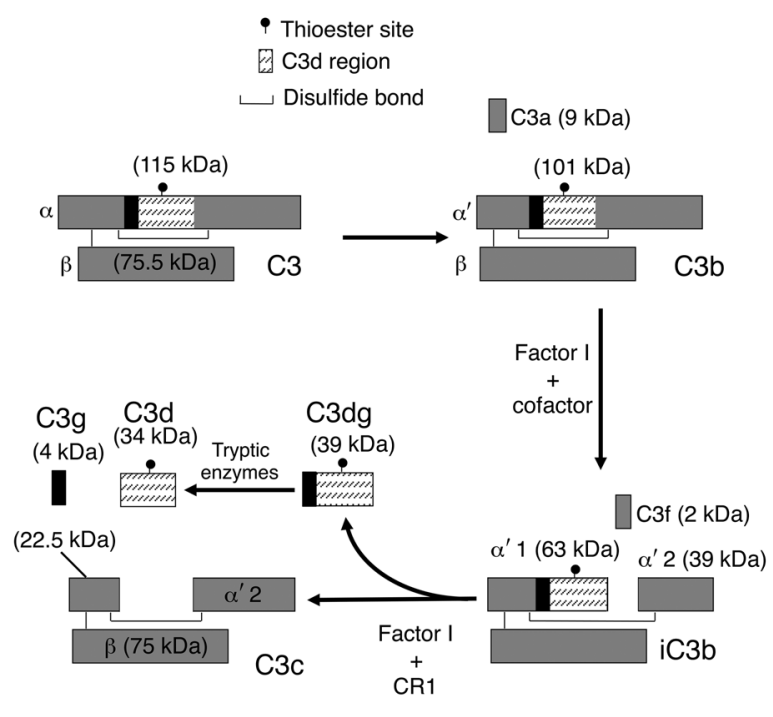

Figure 1

Metabolism of C3 to iC3b and C3d during complement activation. During complement activation, the $\mathrm{C} 3$ protein undergoes proteolytic cleavage at several locations. The C3d domain is present within the C3, C3b, and iC3b molecules. However, conformational changes in the 3D structure of $\mathrm{C} 3$ expose $\mathrm{C} 3 \mathrm{~d}$ epitopes during cleavage of the $\mathrm{C} 3$ molecule.

expose the hybridoma cells to C3 and C3 fragments in serum-containing media, or to $\mathrm{C} 3$ synthesized by cells, such as macrophages, that are used in the cultures. C3 and C3 fragments in the media could mask positive hybridoma clones or affect the growth of such clones through engagement of the B cell receptors.

We have used novel methods to overcome these difficulties and have developed 9 murine monoclonal antibodies against human C3d that cross-react with both mouse and cynomolgus C3d. Three of these high-affinity antibodies discriminate the cleaved forms of C3 from the intact C3 protein. Furthermore, our studies demonstrate that these antibodies can be used to target tissue sites of complement activation in vivo despite high levels of intact $\mathrm{C} 3$ in the circulation. We report herein the methods that we used to develop these monoclonal antibodies against C3d and the evidence that these reagents target tissue-bound C3d in vivo.

\section{Results}

Development of murine $m A$ bs against recombinant buman $C 3 d$. During complement activation, C3 undergoes a conformational change that exposes a reactive thioester bond $(9,17)$. The thioester domain (TED) of $\mathrm{C} 3$ rotates during the conversion of $\mathrm{C} 3$ into $\mathrm{C} 3 \mathrm{~b}$, altering the orientation of the TED on the surface of the molecule (17). Domains within this region of $\mathrm{C} 3 \mathrm{~b}$ become increasingly exposed during the subsequent cleavages that generate iC $3 \mathrm{~b}, \mathrm{C} 3 \mathrm{dg}$, and finally C $3 \mathrm{~d}$ (Figure 1). In order to generate $\mathrm{mAbs}$ against epitopes on this region of $\mathrm{C} 3$, we produced recombinant human $\mathrm{C} 3 \mathrm{~d}$ using an $E$. coli expression system (18) and immunized mice bearing a targeted deletion of the $C 3$ gene (C3-/- mice) (19). Although $\mathrm{C}^{-1-}$ mice have impaired humoral immunity (19), immunization of these mice has previously been used to generate antibodies against human C3 (20). We found that $\mathrm{C3}^{-/-}$mice immunized with recombinant $\mathrm{C} 3 \mathrm{~d}$ immunogen in adjuvant developed a strong humoral response to $\mathrm{C} 3 \mathrm{~d}$ (data not shown).
Two fusions were performed using splenocytes of mice with high antibody titers against C3d, but both fusions failed to yield any reactive clones. Because the desired hybridomas would produce monoclonal antibodies specific to $\mathrm{C} 3 \mathrm{~d}$, we hypothesized that the failure to generate any clones was because $\mathrm{C} 3$ fragments generated by serum in the tissue culture media or from macrophages used in the cloning process bound to the $\mathrm{B}$ cell receptors of the reactive cells. This could potentially lead to apoptosis of the cells or interfere with the screening ELISA assay. Therefore, a third fusion was performed in which hybridomas were grown in serum-free media formulations. Because macrophages also have the capacity to synthesize all of the proteins of the alternative complement pathway and generate C3 fragments (21), the feeder cells used during cloning were obtained by peritoneal lavage of $\mathrm{C}^{-/-}$mice. Single-cell clones were generated and screened against C3d by ELISA, and 9 hybridomas producing monoclonal antibodies with strong ELISA reactivity against human C3d were identified (Figure 2A). This ELISA was repeated multiple times during the cloning and purification process, and a representative experiment is shown.

To confirm that the monoclonal antibodies reacted with $\mathrm{C} 3 \mathrm{~d}$ and not with a contaminant in the immunogen, the antibodies were tested against C3d using a sandwich ELISA in which recombinant C3d was captured with a polyclonal anti-C3d capture antibody. To test the reactivity of the clones against murine C3d (which has $84 \%$ sequence identity with human C3d), we performed indirect and sandwich ELISAs using recombinant murine C3d. We also performed direct ELISAs to test binding of the antibodies to recombinant human $\mathrm{C} 3 \mathrm{~d}$ from a second construct as well as to commercially available purified human $\mathrm{C} 3 \mathrm{~d}$, and to recombinant cynomolgus $\mathrm{C} 3 \mathrm{~d}$. The 9 clones all showed strong reactivity against each of these targets (data not shown). To test the antibodies for cross-reactivity against other plasma proteins, the C3d ELISA was repeated in the presence of wild-type and $\mathrm{C}^{-/-}$mouse serum (Figure 3). Serum was added across a range of dilutions (1:5 to $1: 6,400)$, and no effect on the binding of the antibodies to C3d was observed. Specificity of $m A b s 3 d 8 b, 3 d 9 a$, and $3 d 29$ to $C 3$ activation fragments. Western blot analysis of human C3 and C3d was performed following separation of C3d and C3 fragments by SDS-PAGE, and the blots were probed with the 9 anti-C 3 d clones. Although one might expect epitopes recognized in SDS-denatured C3d to also be exposed on the intact C $3 \alpha$ chain in its denatured form, the antibodies demonstrated differential recognition of $\mathrm{C} 3$ and $\mathrm{C} 3 \mathrm{~d}$ in this assay (Figure 2B). The antibodies displayed 3 distinct binding patterns by Western blot analysis: strong binding to $\mathrm{C} 3 \mathrm{~d}$ without substantial binding to C3 (Group 1); strong binding to the C3 $\alpha$ chain and C3d (Group 2); or weak binding to both proteins (Group 3). A commercially available polyclonal antibody against mouse C3 (MP Biomedicals; product 55557) bound fragments that approximate the sizes of the $\alpha$ and $\beta$ chains of C 3 and is shown on the right-most blot for comparison. The lower molecular weight bands may represent contaminants or degraded C3. Antibodies from each group displayed nearly identical patterns when run side by side (data not shown). Clone $3 \mathrm{~d} 11$ recognized all of the C3 $\alpha$ chain fragments by Western blot analysis (Figure 2C).

To evaluate the binding of the antibodies to the different $\mathrm{C} 3$ fragments in their native form, immunoprecipitation reactions were performed using activated murine serum that contained a mixture of the various C3 fragments (Figure 2D). The immunoprecipitated proteins were then detected by Western blot analysis with $\mathrm{mAb} 3 \mathrm{~d} 11$. Antibodies $3 \mathrm{~d} 8 \mathrm{~b}$ and $3 \mathrm{~d} 29$ (Group 1) pulled down 
A
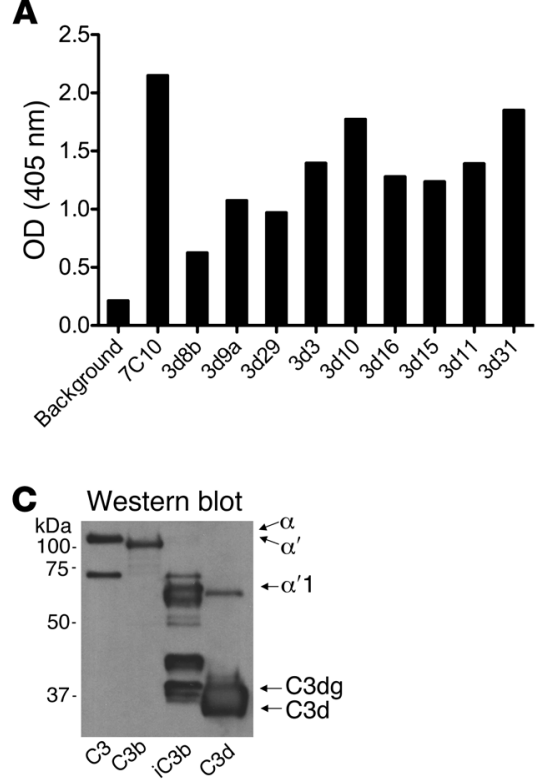
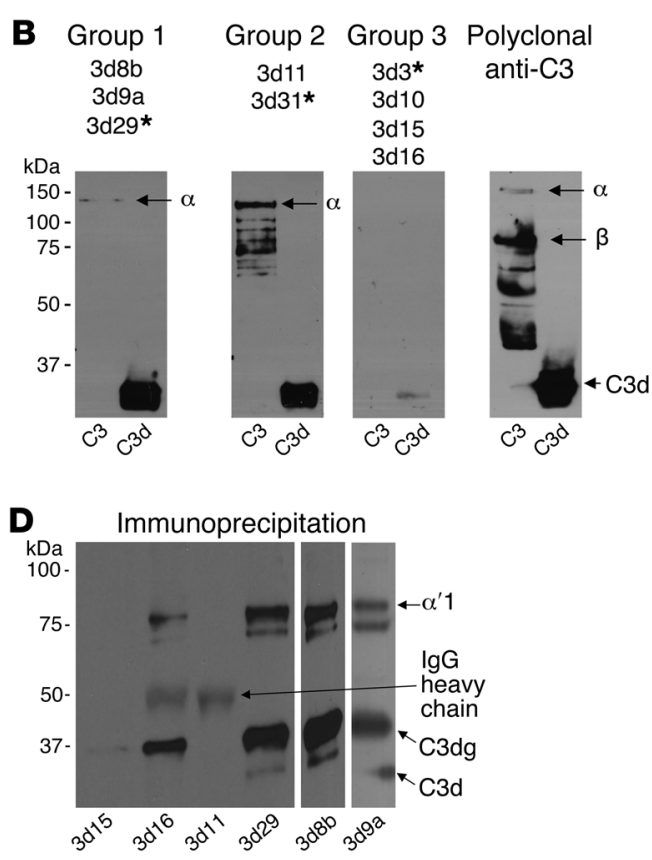

Figure 2

Generation of mAbs that recognize $\mathrm{C} 3$ activation fragments. Anti-human $\mathrm{C} 3 \mathrm{~d}$ hybridomas were generated. (A) The hybridomas were screened against recombinant human C3d by ELISA, and 9 of the clones bound to the protein (clone $7 \mathrm{C} 10$ was used as a positive control, and the remaining clones were newly identified). (B) Reactivity of the clones against reduced intact human C3 and recombinant human C3d by Western blot analysis was tested. Three patterns of reactivity were seen: Group 1 clones bound strongly to reduced C3d; Group 2 clones bound to the $\alpha$ chain of reduced intact C3; and Group 3 clones did not bind well to either moiety. The asterisk denotes the mAb whose results are shown. The rightmost blot shows the result using a polyclonal antibody against mouse C3. The lower molecular weight bands detected by the mAbs in the $\mathrm{C} 3$ samples are likely contaminants. (C) Clone $3 \mathrm{~d} 11$ recognized all of the human C3 $\alpha$ chain fragments by Western blot analysis. The appearance of the $\alpha, \alpha^{\prime}, \alpha^{\prime} 1$, C3dg, and C3d fragments from purified human proteins are shown. The lower molecular weight bands detected in the C3 and iC3b samples are likely contaminants. (D) Immunoprecipitation of C3 fragments in mouse serum demonstrated that the Group 1 clones recognize the iC $3 b$ form ( $\alpha^{\prime} 1$ chain) and C3dg, but do not bind to the $\mathrm{C} 3$ and $\mathrm{C} 3 \mathrm{~b}$ ( $\alpha$ and $\alpha^{\prime}$ chains). Clone $3 \mathrm{~d} 16$ demonstrated some binding to the iC3b and C3dg fragments. The results using $3 \mathrm{~d} 8 \mathrm{~b}$ were from a separate gel. The immunoprecipitated proteins were visualized by Western blot analysis with mAb 3d11 under reducing conditions.

murine iC3b, C3dg, and C3d fragments; $3 \mathrm{~d} 11$ (Group 2) did not pull down any murine C3 fragments; and $3 \mathrm{~d} 16$ (Group 3) pulled down iC3b and C3dg fragments.

The affinities of mAbs $3 d 8 b, 3 d 9 a$, and $3 d 29$ for human C3d were tested by surface plasmon resonance (Figure 4). The measured affinities were: $3 \mathrm{~d} 8 \mathrm{~b}: \mathrm{K}_{\mathrm{D}}=0.47 \mathrm{nM}$; $3 \mathrm{~d} 9 \mathrm{a}: \mathrm{K}_{\mathrm{D}}=0.37 \mathrm{nM}$; and $3 \mathrm{~d} 29: \mathrm{K}_{\mathrm{D}}=1.06 \mathrm{nM}$.

Effects of anti-C3d mAbs on surface-bound C3 convertase activity. The alternative pathway $\mathrm{C} 3$ convertase is composed of $\mathrm{C} 3 \mathrm{~b}$ in complex with the factor $\mathrm{B}$ fragment $\mathrm{Bb}$ and the fluid-phase protein properdin $(\mathrm{P})$. While $\mathrm{C} 3 \mathrm{bBbP}$ dissociation occurs spontaneously ( $\mathrm{T}_{1 / 2} \sim 5-10$ minutes), this process is greatly accelerated by the

\section{Figure 3}

Proteins in mouse serum do not reduce the binding of $3 d 29$ to platebound C3d. The anti-C3d mAbs were tested in a C3d ELISA in which increasing concentrations of serum from wild-type and C3-deficient $\left(\mathrm{C}^{---}\right)$mice were added to the reactions. Binding of the anti-C3d mAbs was not reduced by wild-type or $\mathrm{C}^{-/-}$serum in any of the dilutions tested. The results for $\mathrm{mAb} 3 \mathrm{~d} 29$ are shown. fluid-phase complement regulator factor $H$. This latter reaction plays a critical role in protecting cells and tissues from complement-mediated damage and in preserving $\mathrm{C} 3$ homeostasis. Certain anti-C3 autoantibodies, referred to as $\mathrm{C} 3$ nephritic factors (C3Nef), stabilize the alternative pathway C3 convertase and confer to it resistance to factor $\mathrm{H}$, thus permitting uncontrolled complement activation (22). To assess whether the anti-C3d antibodies have C3Nef-like activity, we first incubated human C3bBbP complexes preassembled on sheep erythrocytes with the antiC3d antibodies or with buffer alone for various durations. We then quantified the hemolytic activity of the remaining convertases (Figure 5A). The Group $1 \mathrm{mAbs}(3 \mathrm{~d} 8 \mathrm{~b}$, $3 d 9 a$, and $3 d 29$ ) did not have any effect on erythrocyte lysis, nor did the Group 2 clone $3 \mathrm{~d} 31$. The loss of hemolytic activity due to spontaneous convertase dissociation during the incubation period in these samples was comparable to that of the control cells. In contrast, the Group 3 clones ( $3 \mathrm{~d} 3,3 \mathrm{~d} 15$, and $3 \mathrm{~d} 16)$ stabilized the convertase, causing greater erythrocyte lysis immediately (Figure $5 \mathrm{~A}$ ), and after a 2-hour incubation period (Figure $5 \mathrm{~B}$ ). In all cases, hemolysis was absolutely dependent on the presence of factor $\mathrm{B}$ in the preassembly step (Figure 5, C and D), thus confirming that the alternative pathway $\mathrm{C} 3$ convertase mediated the Group 3 effects. EGTA was included as a calcium chelator, thus precluding the involvement of the other complement activation pathways in the process.

We also examined the impact of the anti-C3d antibodies on factor $\mathrm{H}$ activity. Factor $\mathrm{H}$ is an alternative pathway regulatory protein that limits alternative pathway activation by accelerating the decay of C3 convertase (23) or by serving as a cofactor for factor I-

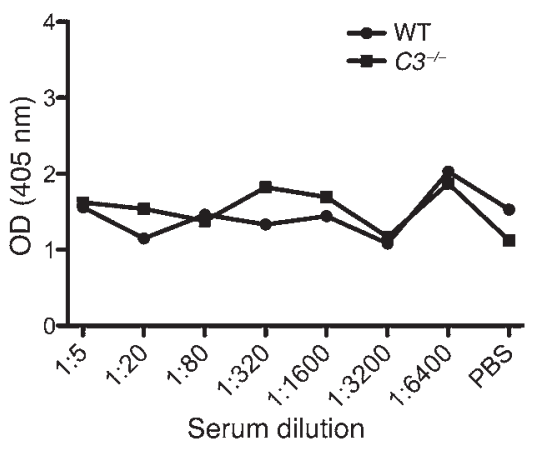



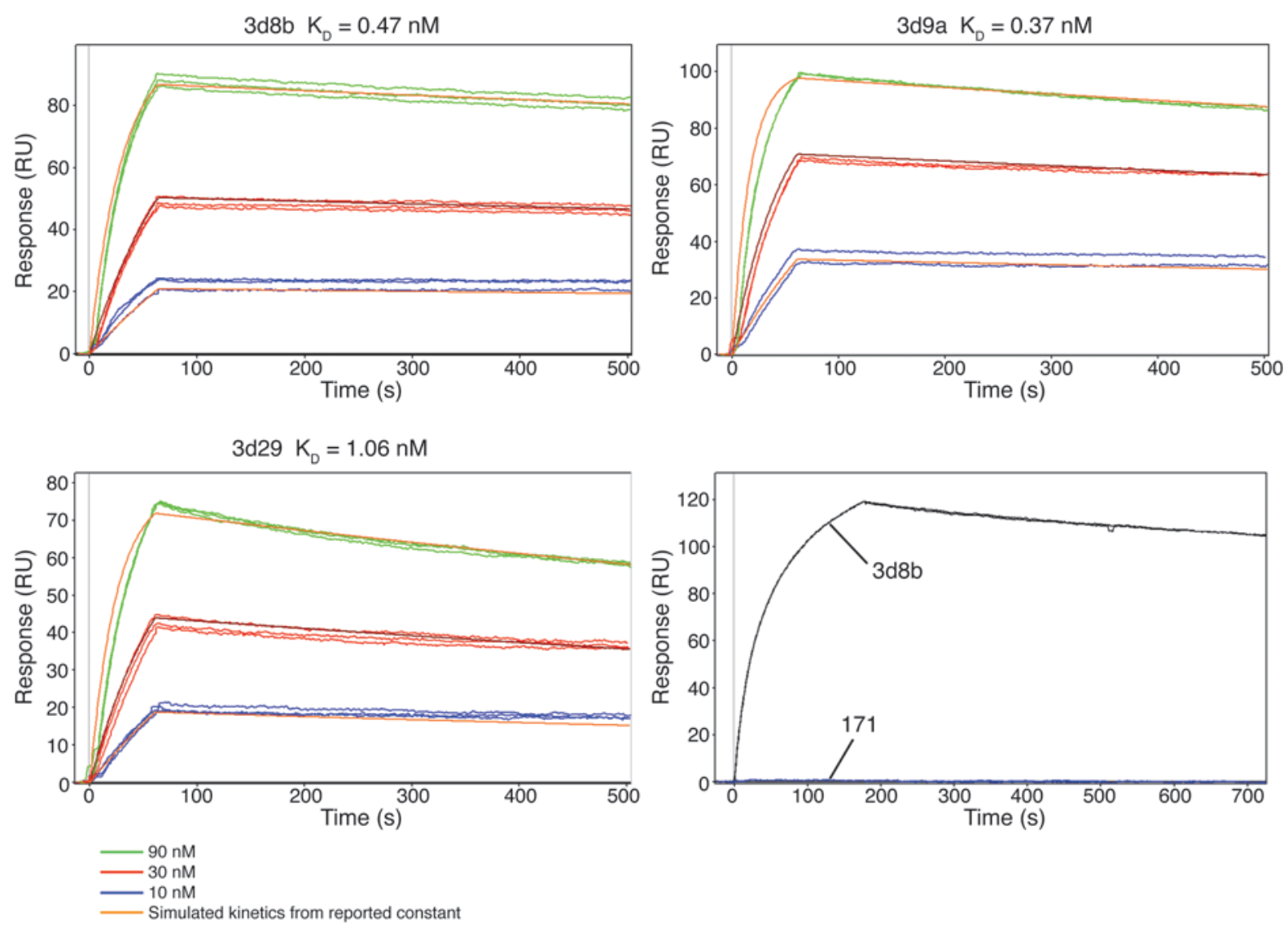

Figure 4

Surface plasmon resonance of clones 3d8b, 3d9a, and 3d29 against recombinant human C3d demonstrate high-affinity binding. Surface plasmon resonance was performed using recombinant human C3d. The protein was immobilized on a CM5 chip (100 RU), and samples containing variable concentrations of the antibodies $(90,30$, or $10 \mathrm{nM})$ were added. The data were fitted using a 1:1 Langmuir binding model and equilibrium dissociation constants $\left(K_{D}\right)$ were calculated. mAb 171 was used as a negative control, and the results of binding with $\mathrm{mAb} 171$ (blue line) were compared with the results using $\mathrm{mAb}$ and $\mathrm{mAb} 3 \mathrm{~d} 8 \mathrm{~b}$, both at $90 \mathrm{nM}$. The anti-C3d mAbs demonstrated high-affinity binding, and the $\mathrm{K}_{\mathrm{D}} \mathrm{S}$ are shown for each mAb studied.

mediated cleavage (inactivation) of $\mathrm{C} 3 \mathrm{~b}$ (24). The addition of factor $\mathrm{H}$ inhibited lysis of the erythrocytes in reactions containing each of the anti-C3d antibodies, indicating that none of the antibodies blocked the factor $\mathrm{H}$ binding site on the surface of $\mathrm{C} 3 \mathrm{~b}$ (Figure 5E). This is consistent with recent data indicating that the binding site on $\mathrm{C} 3 \mathrm{~b}$ for the amino-terminal 4 short consensus repeats (SCRs) of factor $\mathrm{H}$ (CFH1-4), which harbor the factor I cofactor and $\mathrm{C} 3 \mathrm{bBb}$ decay acceleration activities of factor $\mathrm{H}$, lies outside the TED domain (which approximates to the C3d cleavage product) (25). Finally, the antibodies were tested in an alternative pathway hemolysis assay using normal human serum and rabbit erythrocytes. This is a standard assay for measuring alternative pathway activity on activator surfaces. Even when clones $3 \mathrm{~d} 8 \mathrm{~b}$, $3 \mathrm{~d} 9 \mathrm{a}$, and $3 \mathrm{~d} 29$ were added to the reaction mix at high concentrations, they did not increase erythrocyte lysis (data not shown).

Effect of anti-C3d mAbs on binding of C3d by CR2. C3d is a ligand for CR2, which is expressed on B cells and follicular dendritic cells. Recognition of C3d by CR2 on B cells lowers the threshold for $\mathrm{B}$ cell activation by the $\mathrm{B}$ cell receptor (26). CR2 also binds to the iC $3 b, C 3 d g$, and C3d fragments of C3, similar to the Group 1 monoclonal antibodies. Consequently, signaling by CR2 is impor- tant in the development of the humoral immune response and autoimmunity (16). We tested whether the mAbs against C3d block this interaction (Figure 6A). Using an in vitro CR2-C3d binding assay, we found that clones $3 \mathrm{~d} 8 \mathrm{~b}, 3 \mathrm{~d} 9 \mathrm{a}, 3 \mathrm{~d} 11,3 \mathrm{~d} 29$, and $3 \mathrm{~d} 31$ blocked CR2 from binding C3d, whereas the other antibodies did not. Dose response curves for the Group 1 antibodies demonstrated nearly complete inhibition of CR2 binding by $3 \mathrm{~d} 8 \mathrm{~b}$ (Figure 6B). Clones 3d9a and 3d29 achieved approximately $80 \%$ inhibition of binding by CR2 when added at high concentrations (Figures 6, C and D). The inability of $3 \mathrm{~d} 10$ to block CR2 binding at any of the concentrations tested is shown in Figure 6E. These results raise the possibility that $\mathrm{mAbs} 3 \mathrm{~d} 8 \mathrm{~b}, 3 \mathrm{~d} 9 \mathrm{a}, 3 \mathrm{~d} 11,3 \mathrm{~d} 29$, and $3 \mathrm{~d} 31$ may have immunomodulatory function.

Binding of anti-C3d mAbs to surface-bound $\mathrm{C} 3$ activation fragments in vitro. To assess the ability of the mAbs to bind native $\mathrm{C} 3$ fragments bound to activating surfaces, zymosan particles were opsonized with C3 fragments by incubation with mouse serum (27). The particles were then incubated with the antibodies, and bound antibodies were detected by flow cytometry (Figure 7A). mAbs $3 \mathrm{~d} 8 \mathrm{~b}, 3 \mathrm{~d} 9 \mathrm{a}$, and $3 \mathrm{~d} 29$ bound to the opsonized zymosan particles, whereas the other mAbs did not. To test whether intact $\mathrm{C} 3$ or C3 

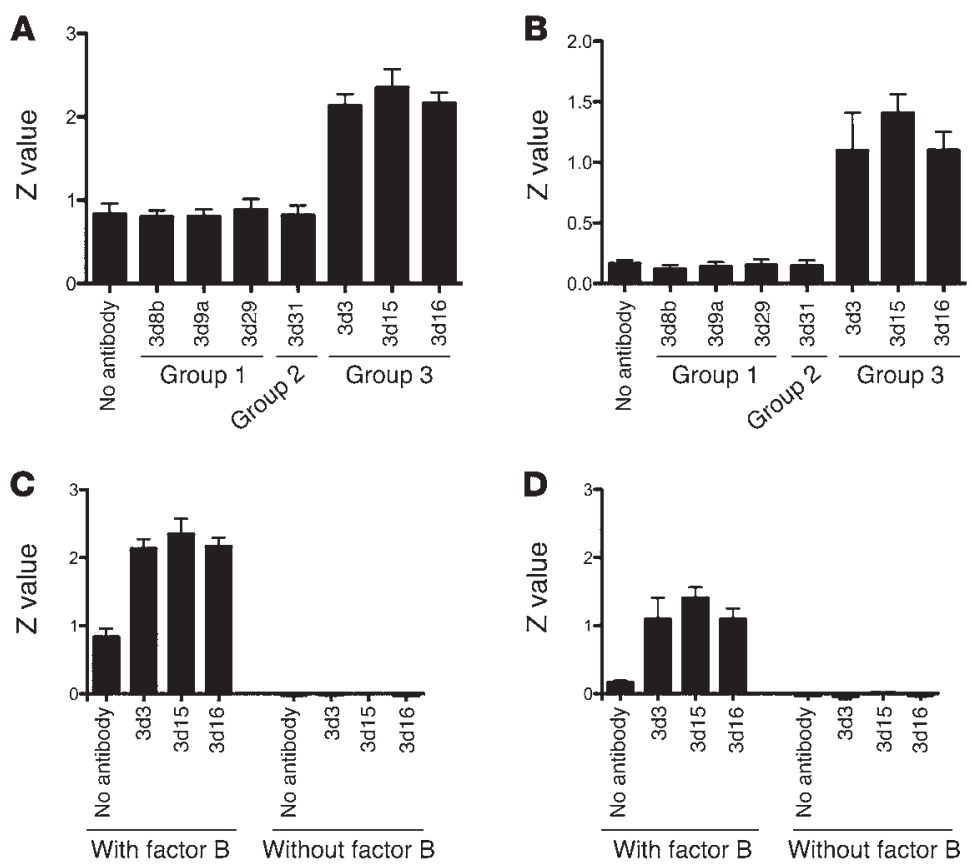

\section{Figure 5}

Clones $3 \mathrm{~d} 3,3 \mathrm{~d} 15$, and $3 \mathrm{~d} 16$ stabilize $\mathrm{C} 3$ convertase on sheep erythrocytes. Sheep erythrocytes were sensitized with antibody and opsonized with human C3b. They were then treated with factor $B$, factor $D$, and properdin to generate AP $\mathrm{C} 3$ convertases $(\mathrm{C} 3 \mathrm{bBbP})$ on the cell surfaces. One microgram of antibody was added to a $150-\mu$ l reaction mix, and the cells were used immediately $(\mathbf{A}$ and $\mathbf{C})$ or incubated for 2 hours (B and D). $n=4-6$ for each condition. (A) When guinea pig serum was added to the erythrocytes as a source of MAC and the average number of lytic sites was calculated ( $Z$ value), cells treated with clones $3 d 3,3 d 15$, and $3 d 16$ demonstrated a greater MAC formation than control-treated cells. (B) When the cells were incubated 2 hours prior to addition of the guinea pig serum, the same 3 clones showed greater $Z$ values, indicating that these clones stabilize the C3 convertase on the cell surface. (C and $\mathbf{D}$ ) The experiment was repeated for clones $3 \mathrm{~d} 3,3 \mathrm{~d} 15$, and $3 \mathrm{~d} 16$ in the presence or absence of factor B. In the absence of factor B, MAC formation was eliminated, demonstrating that the reaction required formation of the alternative pathway $\mathrm{C} 3$ convertase. (E) The same reaction was repeated but with the addition of $400 \mathrm{ng}$ of factor $\mathrm{H}$. None of the antibodies tested interfered with the ability of factor $\mathrm{H}$ to dissociate the $\mathrm{C} 3$ convertase and prevent MAC formation. This experiment was performed in duplicate, and the mean of these results is shown.

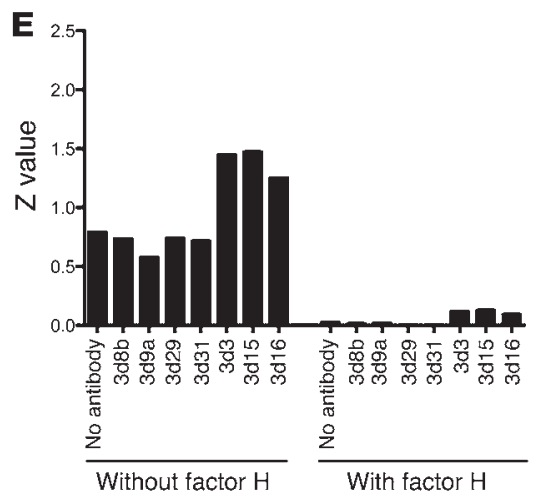

activation fragments in serum could compete with the C3 fragments on the zymosan surface, this assay was repeated and the particles were incubated with antibody in the presence of activated or fresh serum (Figure 7, B and C). The addition of serum to the reactions did not reduce binding of the antibody to the particles.

To test the binding of these antibodies to $\mathrm{C} 3$ deposits in tissues, sections were made from the kidneys of factor $\mathrm{H}$-deficient $\left(\mathrm{fH}^{-/-}\right)$ mice. The glomeruli of these mice are characterized by glomerulonephritis and have abundant deposits of the $\mathrm{C} 3$ activation fragments iC3b and C3dg/C3d (28, 29). Clones 3d8b, 3d9a, and 3d29 bound to sites in the acetone-fixed sections in a pattern indistinguishable from that obtained using a polyclonal antibody against C3 (Figures 8, A and B). 3d8b, 3d9a, and 3d29 did not bind to the glomeruli of factor I-deficient mice (Figure 8B; results not shown for $3 \mathrm{~d} 8 \mathrm{~b}$ and $3 \mathrm{~d} 9 \mathrm{a}$ ), confirming that the antibodies are specific to downstream cleavage fragments (iC3b, C3dg, and C3d).

In vivo targeting of anti-C3d mAbs to tissue sites of complement activation. Next, we sought to determine whether the antibodies would bind to tissue-bound C3 fragments when injected in vivo. The antibodies were injected intravenously into $\mathrm{fH}^{-/-}$mice, which do not have glomerular deposits of endogenous IgG (29). After 24 hours, the kidneys were harvested and immunostained for IgG
(Figure 9A). mAbs $3 \mathrm{~d} 8 \mathrm{~b}, 3 \mathrm{~d} 9 \mathrm{a}$, and $3 \mathrm{~d} 29$ were readily detected along the glomerular basement membrane in a pattern indistinguishable from that of the $\mathrm{C} 3$ fragments, demonstrating that they bound to C3 deposits in the glomerular capillary wall after intravenous injection. To confirm that we were not detecting endogenous deposits of IgG, $\mathrm{mAb} 3 \mathrm{~d} 29$ was biotinylated and injected into $\mathrm{fH}^{-/-}$mice. Glomerular binding of the antibody was detected using streptavidin-FITC (Figure 9A).

C3 fragments are ordinarily deposited along the tubular basement membrane of wild-type mice (30). Tubular C3 deposits are not seen in $\mathrm{fH}^{-/}$mice, likely because most $\mathrm{C} 3$ is consumed in the fluid phase in these mice $(29,31)$. No IgG was detected along the tubular basement membrane of $\mathrm{fH}^{-/-}$mice injected with the anti-C3d antibodies. However, when biotinylated 3d29 was injected into wild-type mice, it was detected along the tubular basement membrane and colocalized with the $\mathrm{C} 3$ deposits (Figure 9B). These results indicate that mAbs $3 \mathrm{~d} 8 \mathrm{~b}, 3 \mathrm{~d} 9 \mathrm{a}$, and $3 \mathrm{~d} 29$ target and bind to tissue deposits of $\mathrm{C} 3$ activation fragments in the glomeruli of nephritic mice and in the tubulointerstitium of unmanipulated wild-type mice.

In vivo imaging of anti-C3d $m$ Abs targeted to ocular sites of complement activation. To test whether the targeted antibodies could be visualized in vivo, we turned to a system amenable to optical imaging, 
A
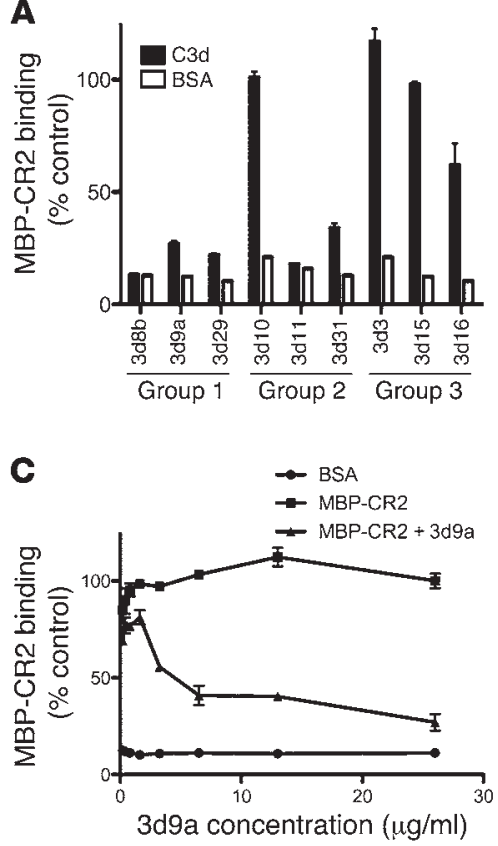

B

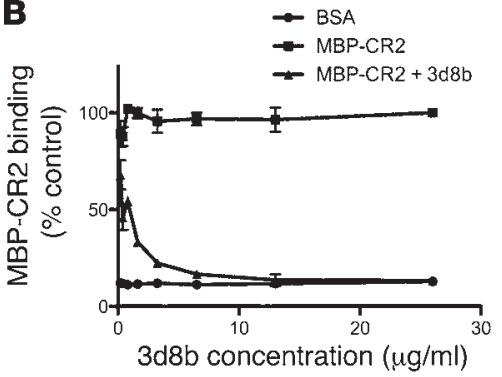

D

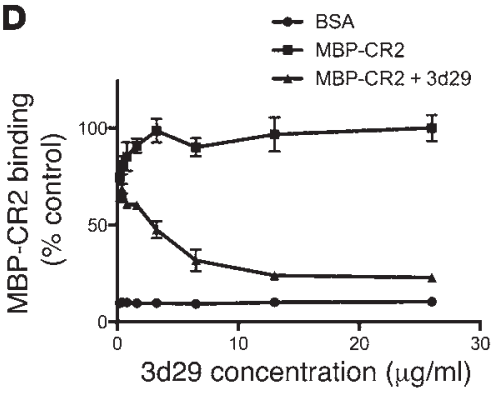

\section{Figure 6}

Inhibition of the CR2-C3d interaction by anti-C3d mAbs. (A) A competition ELISA was performed to test whether the anti-C3d mAbs interfere with the binding of a recombinant construct of the $2 \mathrm{~N}$-terminal domains of CR2 (MBP-CR2) and plate-bound C3d. The percentage of MBP-CR2 binding ( $y$-axis) (kept at a constant concentration of $10 \mu \mathrm{g} / \mathrm{ml}$ ) to C3d was determined in the presence of individual anti-C3d mAbs ( $x$-axis) at a concentration of $26 \mu \mathrm{g} / \mathrm{ml}$. Values are normalized to a positive control in which $\mathrm{C} 3 \mathrm{~d}$-coated wells were incubated with MBP-CR2 in the absence of anti-C3d mAbs (not shown). Also shown for each sample is a negative control in which the wells were coated with BSA instead of C3d. (B-D) Capacity of the Group 1 mAbs (3d8b, 3d9a, and 3d29) to block MBP-CR2 binding to plate-bound $\mathrm{C} 3 \mathrm{~d}$ at $\mathrm{mAb}$ concentrations ranging from 1.625 to $26 \mu \mathrm{g} / \mathrm{ml}$. (E) $3 \mathrm{~d} 10 \mathrm{did}$ not block the binding of CR2 to plate-bound C3d over the same concentration range.

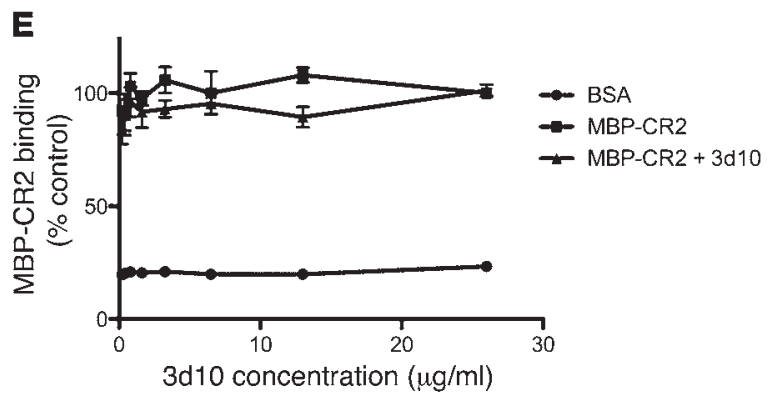

the eye. Complement activation is involved in the pathology of age-related macular degeneration (AMD). Complement components, including C3 (7), anaphlatoxins C3a and C5a (32), as well as components of the membrane attack complex (MAC) (7) have been identified within pathological structures in AMD (e.g., drusen, Bruch's membrane), and single nucleotide polymorphisms in complement genes are risk factors for AMD (33). AMD results in vision loss from either atrophy of the retinal pigmented epithelium (RPE) followed by loss of photoreceptors, or choroidal neovascularization (CNV) followed by loss of photoreceptors. The latter process can be mimicked in mice by damaging the blood-retina barrier using laser photocoagulation, which triggers ingrowth of choroidal blood vessels into the subretinal space in a complement-dependent fashion (11). Likewise, complement deposition has been shown to occur at the site of injury $(11,32)$. Using the systemic CR2 targeting strategy, we have shown that complement inhibition delivered in this fashion (CR2-fH) can ameliorate CNV $(11,12)$.

We evaluated whether we could directly image complement activation in the RPE/choroid of laser-damaged mice using the anti-C3d mAbs. First, we tested the antibodies to determine which of them recognize $\mathrm{C} 3 \mathrm{~d}$ epitopes in the $\mathrm{CNV}$ lesion sites in flat-mounted $\mathrm{RPE} /$ choroid. Since fluorescently labeled antibodies are required for in vivo imaging, only FITC-labeled antibodies were tested. Of the FITC-labeled mAbs, clone $3 \mathrm{~d} 29$ demonstrated the best binding to the $\mathrm{CNV}$ lesion in lightly fixed tissues ( $4 \%$ paraformaldehyde for
30 minutes) (Figure 10A). An isotype control antibody (HB5) was also tested in order to confirm the specificity of binding by $3 \mathrm{~d} 29$ (Figure 10B). Since complement factor B knockout mice $\left(\mathrm{fB}^{-/-}\right)$show no increase in $\mathrm{C} 3$ in the $\mathrm{RPE} /$ choroid in response to the lesion and fail to develop significant $\mathrm{CNV}(11), \mathrm{fB}^{-/-}$mice were used as negative controls for FITC-labeled mAb binding (Figure 10C).

For in vivo imaging, CNV lesions were generated and $200 \mu \mathrm{g}$ ( $200 \mu \mathrm{l}$ of antibody at a concentration of $1 \mathrm{mg} / \mathrm{ml}$ ) of FITC-labeled $3 \mathrm{~d} 29$ or HB5 was injected intravenously on day 3 after CNV induction, a time point previously shown to correspond to the peak of C3 deposition within the lesion (11). We used fundus imaging of the animals 6, 24, and 48 hours after the injection. The CNV lesions are readily apparent in bright-field images as depigmented areas (Figure 10, D and F). At the 6-hour time point, unbound FITC-labeled antibody was still visible in the retinal and choroidal vasculature, obscuring positive staining. Twenty-four hours after antibody injection, a strong fluorescent signal was detected in the CNV lesions of 3d29-injected mice (Figure 10G). Little signal was detected in the lesions of HB5-injected mice (Figure 10E). At 48 hours, while the positive signal for $3 \mathrm{~d} 29$-injected mice was still present, the intensity was less pronounced. These results indicate that $3 \mathrm{~d} 29$ is retained in $\mathrm{RPE} /$ choroidal tissue deposits of $\mathrm{C} 3$ activation fragments at the posterior pole of CNV-lesioned mice at a high enough concentration that it can be visualized in the living eye using conventional imaging techniques. 
A

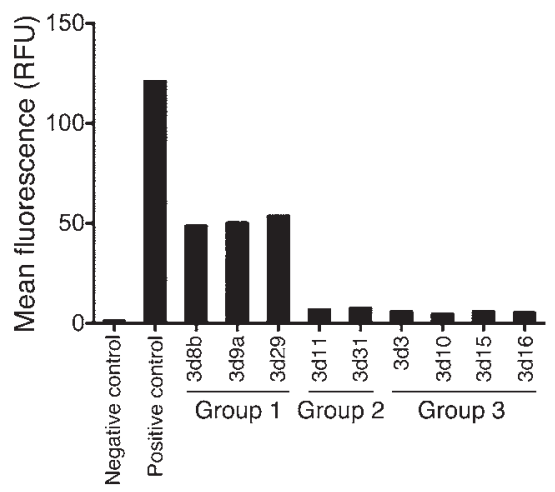

B

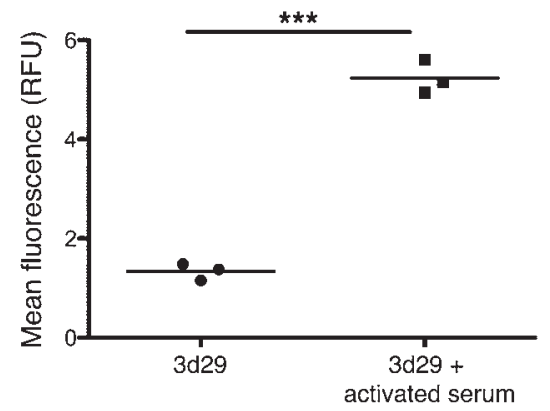

C

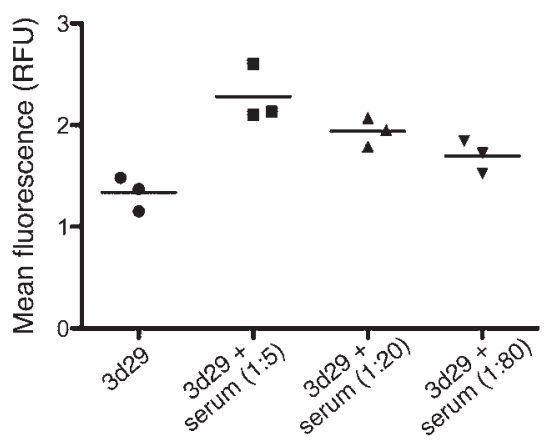

\section{Discussion}

This report describes the development of $3 \mathrm{mAbs}$ (the Group 1 antibodies $3 \mathrm{~d} 8 \mathrm{~b}, 3 \mathrm{~d} 9 \mathrm{a}$, and $3 \mathrm{~d} 29$ ) against the $\mathrm{C} 3$ activation fragment $\mathrm{C} 3 \mathrm{~d}$ that do not bind to intact $\mathrm{C} 3$ in its native conformation. These 3 antibodies recognize an epitope on iC3b, C3dg, and C3d that is either generated or exposed during complement activation. This epitope is probably closely related to the CR2 binding site that is buried within the native C3 structure (34). To successfully create these antibodies, we made several modifications to standard methods of hybridoma fusion: the hybridoma cells were grown under serum-free conditions, and macrophages from $\mathrm{C}^{-/-}$mice were used as feeder cells during the cloning process. This approach allowed the generation of $9 \mathrm{mAbs}$ against human C3d that also reacted with murine and cynomolgus $\mathrm{C} 3 \mathrm{~d}$.

mAbs $3 \mathrm{~d} 8 \mathrm{~b}, 3 \mathrm{~d} 9 \mathrm{a}$, and $3 \mathrm{~d} 29$ demonstrated strong binding to SDS-denatured C3d by Western blot analysis, but no detectable binding to SDS-denatured C3 or C3b (Figure 2B). The same mAbs specifically pulled down $\mathrm{iC} 3 \mathrm{~b}, \mathrm{C} 3 \mathrm{dg}$, and C3d from a mixture that also contained intact $\mathrm{C} 3$ and $\mathrm{C} 3 \mathrm{~b}$ (Figure 2D). These $3 \mathrm{mAbs}$ also bound to $\mathrm{C} 3$ fragments on the surface of opsonized zymosan particles in vitro (Figure 7A), demonstrating the ability to bind sur-

\section{Figure 7}

Clones 3d8b, 3d9a, and 3d29 bind to mouse $\mathrm{C} 3$ fragments generated in vitro. (A) Normal mouse serum was activated on zymosan particles, and binding of the antibodies to the C3-opsonized particles was tested. The opsonized particles were incubated with $1 \mu \mathrm{g}$ of each antibody, and bound antibody was detected by flow cytometry. Polyclonal antimouse C3 was used as a positive control. Clones 3d8b, 3d9, and 3d29 bound to the opsonized particles. This assay was repeated on separate occasions, and a representative result is shown. (B) Zymosan particles were opsonized with $\mathrm{C} 3$ using normal mouse serum and were then incubated with biotinylated 3d29. Incubating 3d29 with the particles in the presence of the activated serum failed to reduce binding of $3 \mathrm{~d} 29$ to the particle surface and actually increased binding. ${ }^{* *} P<0.001$. (C) The addition of fresh mouse serum to the supernatant when the antibody was incubated with the particles did not reduce binding of biotinylated $3 \mathrm{~d} 29$ to the particle surface.

face-bound C3 fragments. Certain anti-C3 antibodies are known to stabilize C3 convertases, effectively amplifying complement activation. The 3 clones that target tissue-bound C 3 fragments did not show any activating activity with the use of several different in vitro assays (Figure 5). Based on their ability to compete for CR2 binding to C3d (Figure 6), an overlapping or closely associated binding site is assumed. The Group 3 antibodies ( $3 \mathrm{~d} 3,3 \mathrm{~d} 15$, and $3 d 16$ ) stabilized C3 convertases that were preassembled on sheep red blood cells (Figure 5). None of the antibodies described here prevented factor $\mathrm{H}$-mediated dissociation of the $\mathrm{C} 3$ convertase.

When mice with glomerulonephritis were injected with $\mathrm{mAbs}$ $3 \mathrm{~d} 8 \mathrm{~b}, 3 \mathrm{~d} 9 \mathrm{a}$, or $3 \mathrm{~d} 29$, the antibodies accumulated at the site of C3 fragment deposits within the glomeruli, demonstrating that the antibodies can be used to target tissue-bound $\mathrm{iC} 3 \mathrm{~b}$ and $\mathrm{C} 3 \mathrm{~d}$ at this location (Figure 9A). When injected into wild-type mice, these antibodies bound to $\mathrm{C} 3$ fragments deposited along the tubular basement membrane (which have deposition of $\mathrm{C} 3$ fragments at baseline; Figure 9B). Because $\mathrm{C} 3$ fragments are present in the plasma of $\mathrm{fH}^{-/-}$mice, and wild-type mice have high circulating levels of intact $\mathrm{C} 3$, these experiments verified that $\mathrm{mAbs}$ $3 \mathrm{~d} 8 \mathrm{~b}, 3 \mathrm{~d} 9 \mathrm{a}$, and $3 \mathrm{~d} 29$ preferentially bind to the tissue-bound $\mathrm{iC} 3 \mathrm{~b}$ and C3d activation fragments, even in the presence of circulating $\mathrm{C} 3$ and $\mathrm{C} 3$ fragments.

A major obstacle to the development of a high-affinity targeting protein for $\mathrm{C} 3$ activation fragments is that the protein must distinguish the cleavage fragments from intact $\mathrm{C} 3$. The high affinity of these antibodies for C3d and the ability to deliver agents to sites of C3d deposition in vivo, make them invaluable tools for the development of diagnostic and therapeutic agents. The ability to block the C3d-CR2 interaction further raises the possibility that these antibodies will have immunomodulatory effects. In addition, when used for tissue analysis ex vivo, these antibodies can also be used to specifically detect deposits of iC $3 \mathrm{~b}, \mathrm{C} 3 \mathrm{dg}$, and C3d fragments in tissues (Figure 8). These antibodies cross-react with murine, human, and cynomolgus C3d, making them suitable for both preclinical and clinical studies. We have identified 41 commercially available mAbs against cleavage fragments of human C3 (not including antibodies against $\mathrm{C} 3 \mathrm{a}$ ), 11 of which are described by the vendors as reacting with $\mathrm{iC} 3 \mathrm{~b}$ and/or C3d. None of the available antibodies had been tested for species cross-reactivity, CR2 inhibition, or in vivo targeting, and only 1 of the antibodies is reported as functional in ELISAs, Western blot analysis, flow cytometry, and immunohistochemistry (Quidel antibody A209). Unlike the anti- 
A
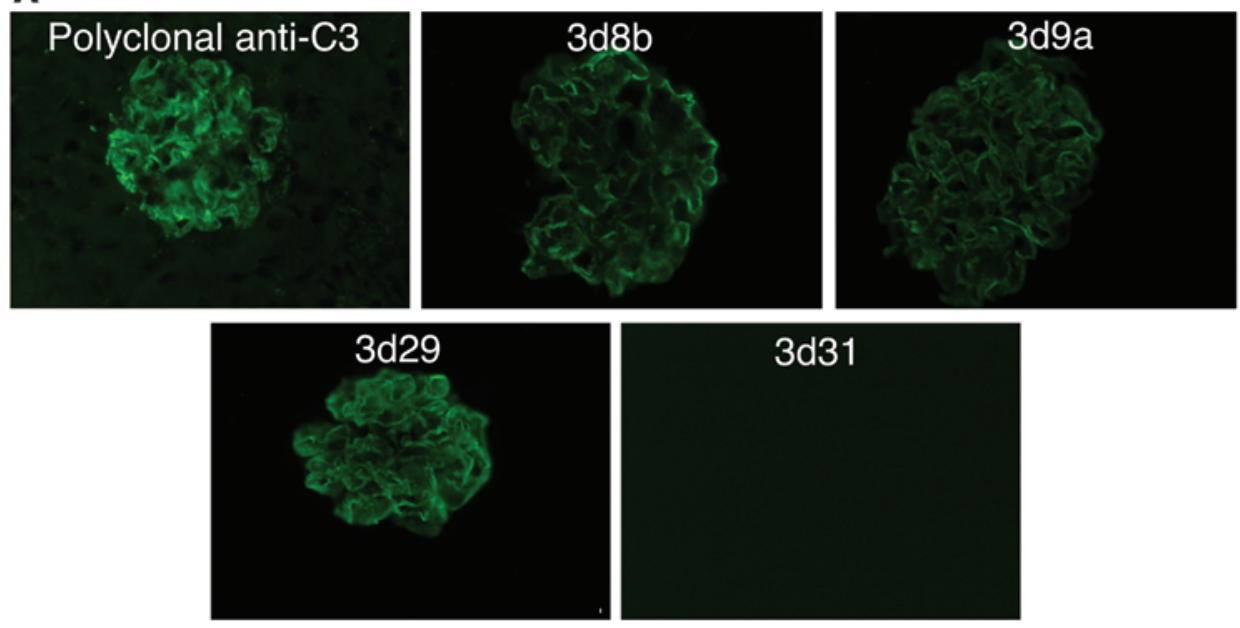

B
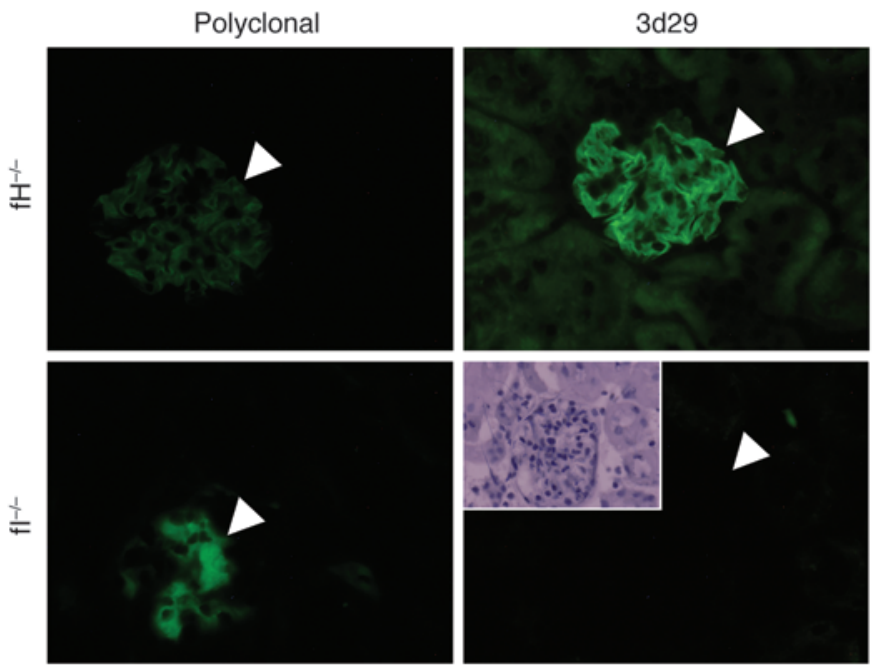

\section{Figure 8}

Clones 3d8b, 3d9a, and 3d29 bind to mouse $\mathrm{C} 3$ fragments generated in vivo. (A) Kidney tissue sections from factor $\mathrm{H}$-deficient mice $\left(\mathrm{fH}^{-/}\right)$ were used to test binding of the antibodies to C3 tissue deposits. Factor $\mathrm{H}$ mice are known to have abundant deposition of C3 fragments along the glomerular capillaries without IgG at this location. This was confirmed by immunostaining with a polyclonal antibody against mouse C3. Kidney tissue sections were then incubated with $5 \mu \mathrm{g} / \mathrm{ml}$ of each clone. Clones $3 d 8 b, 3 d 9$, and $3 d 29$ bound to the capillaries in a pattern identical to that of polyclonal anti-C3. The remaining 6 clones did not demonstrate substantive binding (the result for clone $3 d 31$ is shown). (B) We immunostained kidneys from factor I-deficient $\left(\mathrm{fl}^{-/}\right)$mice with a polyclonal antibody against $\mathrm{C} 3$ and with $\mathrm{mAb} 3 \mathrm{~d} 29$. The $\mathrm{fl}^{-/-}$mice cannot generate iC3b. The absence of glomerular staining in $\mathrm{fl}^{-/-}$mice by mAb $3 d 29$ confirms that the mAb does not recognize C3b. Glomeruli are indicated with arrowheads. Original magnification, $\times 400$ for all panels, including the inset. bodies we are describing (Figure 5), however, that antibody stabilized the C3 convertase on sheep erythrocytes (data not shown). Similarly, 3 other commercial antibodies specific to epitopes in C3d have been tested in this assay and were all found to stabilize the C3 convertase (Dennis Hourcade, unpublished observations). Thus, although a wide range of antibodies against human C3 are available, based on data available from the vendors and based on our own experiments, none of the commercial antibodies against $\mathrm{iC} 3 \mathrm{~b}$ or $\mathrm{C} 3 \mathrm{~d}$ are comparable to $\mathrm{mAbs} 3 \mathrm{~d} 8 \mathrm{~b}, 3 \mathrm{~d} 9 \mathrm{a}$, or $3 \mathrm{~d} 29$.

The detection of glomerular C3 deposition is critical for the accurate diagnosis of glomerulonephritis, and renal biopsy tissue is routinely stained for $\mathrm{C} 3$ fragments. The antibodies and methods described herein may advance our ability to detect and monitor tissue C3 deposition. We have developed an MRI-based method for the noninvasive detection of glomerular C3, and these high-affinity antibodies may improve the sensitivity of this method. In the current study, we demonstrate that FITC-labeled 3d29 was visualized in live animals using conventional fluorescence imaging. This enabled us to noninvasively detect C3d deposits within the RPE/ choroid of mice with CNV. Finally, targeted complement inhibitors have also demonstrated great promise for the treatment of inflammatory diseases $(8,35,36)$. These antibodies may provide a high-affinity targeting vector for the delivery of novel therapeutic agents to sites of tissue inflammation.

A limitation to our characterization of these antibodies is that we have not yet identified the exact epitope of these antibodies. We screened the antibodies against a panel of C3d mutants, but were unable to identify the exact epitope on C3d (data not shown). This suggests that the antibodies may recognize a complex epitope not evaluated by that assay. Epitope mapping studies of these antibodies are underway. However, subtle differences between the antibodies, such as the superior ability of $3 \mathrm{~d} 8 \mathrm{~b}$ to block CR2 binding compared with that of $3 \mathrm{~d} 9 \mathrm{a}$ and $3 \mathrm{~d} 29$, suggest that they recognize distinct epitopes. Identification of the binding site for each antibody may help predict biologic functions of the antibodies, as one may then predict interactions of the $\mathrm{C} 3$ molecules that will be interrupted by the antibodies.

Autoimmune diseases are frequently life long and are characterized by flares and remissions. The immunomodulatory drugs used to treat these diseases are effective, but can cause serious side effects. Thus, as with cancer, the treatment of autoimmune diseases hinges upon the accurate assessment of disease activity. Unfortunately, current molecular imaging methods for detecting tissue inflammation, such as white blood cell scans, lack the sen- 

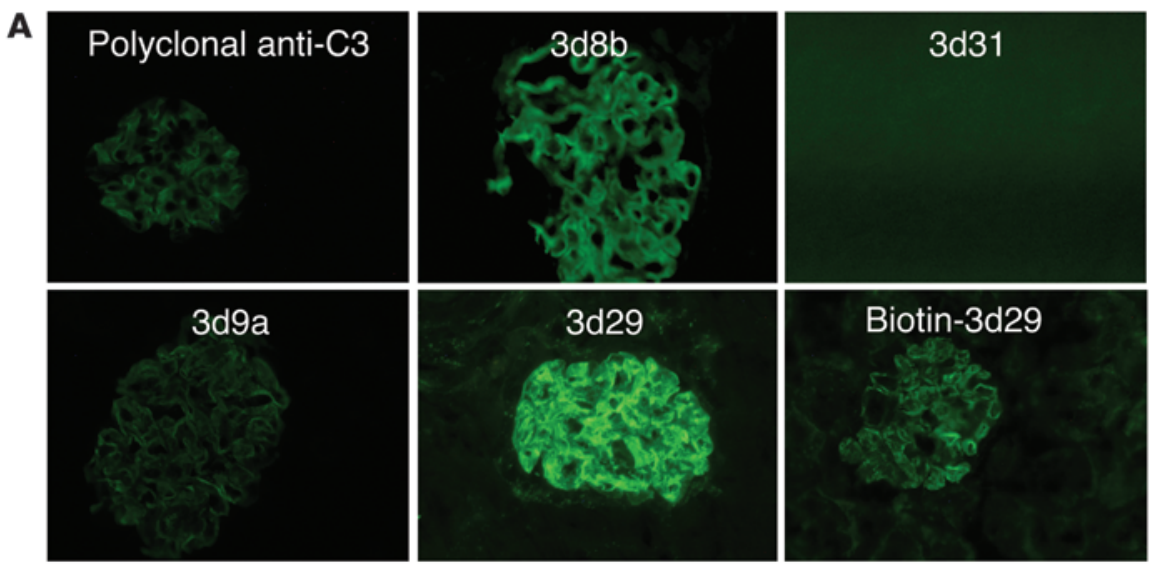

B
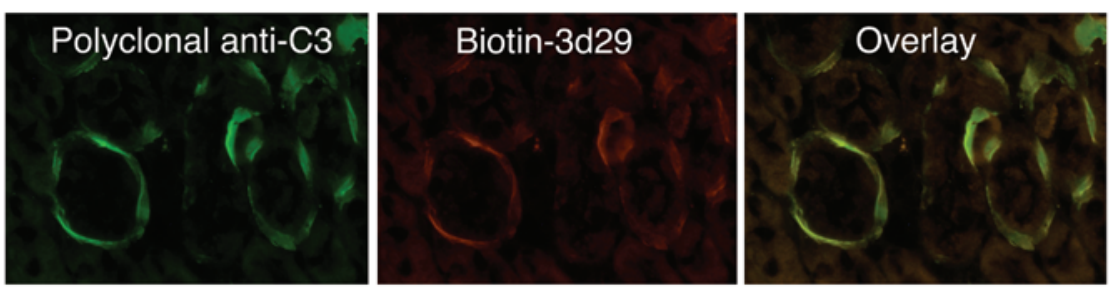

Figure 9

Clones 3d8b, 3d9a, and 3d29 target tissue-bound C3 fragments after systemic in vivo injection. (A) Factor $\mathrm{H}$-deficient mice were injected with $0.5 \mathrm{mg}$ of each antibody. After 24 hours the mice were sacrificed, and immunofluorescence microscopy was performed to detect glomerular IgG. Mice injected with clones 3d8b, 3d9, and 3d29 demonstrated IgG deposition along the capillary walls in a pattern indistinguishable from that of C3 deposition (as shown by control staining of a section with a polyclonal anti-C3 antibody). These mice do not have detectable C3 deposits along the tubules, and no IgG was seen in the tubulointerstitium. To confirm that the detection antibody was not binding to endogenous IgG, clone 3d29 was biotinylated and the experiment was repeated. Streptavidin-FITC was used to detect the injected antibody, and again, it could be seen along the capillary loops. (B) Wild-type C57BL/6 mice demonstrate C3 deposits along the basolateral aspect of the tubules. Unmanipulated C57BL/6 mice were injected with biotinylated $3 \mathrm{~d} 29$ or with a biotinylated control antibody. The mice were sacrificed after 24 hours, and 3d29 was detected in the kidneys using strepatavidin-PE. The antibody was detected along the tubules in a pattern indistinguishable from the C3 deposits. Original magnification, $\times 400$.

sitivity and specificity necessary for monitoring autoimmune disease activity (37). Because $\mathrm{C} 3$ fragments are abundant and durable markers of inflammation, they represent a powerful biomarker of tissue inflammation. Quantitative methods of detecting tissue C3 fragment deposits would improve our ability to monitor a patient's disease activity and response to therapy and would advance the application of "personalized medicine" to the autoimmune diseases. Our studies demonstrate that mAbs $3 \mathrm{~d} 8 \mathrm{~b}, 3 \mathrm{~d} 9 \mathrm{a}$, and $3 \mathrm{~d} 29$ can be employed as molecular imaging probes for the detection of complement activation.

In conclusion, we have successfully generated mAbs against C3 activation fragments. Three of the antibodies recognize breakdown products of $\mathrm{C} 3$ (iC $3 \mathrm{~b}, \mathrm{C} 3 \mathrm{dg}$, and $\mathrm{C} 3 \mathrm{~d}$ ) but do not bind to intact $\mathrm{C} 3$ in its native state. We have demonstrated that these antibodies target tissue-bound C3 fragments in vivo, despite high circulating levels of intact C3. Antibodies specific to tissue-bound C3 activation fragments may be employed for targeted delivery of therapeutic and diagnostic agents to sites of tissue inflammation. Radiologic methods of detecting these antibodies could provide an important new tool for detecting and monitoring tissue inflammation. We have demonstrated that fluorescently labeled antibody was detected in live animals with CNV. Now that therapeutic complement inhibitors have been approved for clinical use (38), noninvasive methods of detecting complement activation within tissues will be increasingly important in therapeutic decision making.

\section{Methods}

\section{Reagents}

Recombinant buman C3d. Recombinant human C3d was used as an immunogen for antibody generation. It was also used as a target antigen in ELISA binding studies and Western blot analysis. C3d was generated using the pGEX expression system (GE Healthcare) in E. coli as previously described (39). The C3d construct comprised amino acids $996-1303$ of the precursor Pro-C3 protein. Briefly, ampicillin-resistant colonies were expanded to 1 liter in Luria-Bertani (LB) broth. The cultures were grown at $37^{\circ} \mathrm{C}$ until an $A_{600}$ of 0.3 was achieved. Cultures were induced with $0.3 \mathrm{mM}$ isopropyl- $\beta$-D-thiogalactoside at $30^{\circ} \mathrm{C}$ overnight before harvesting by centrifugation. Harvested pellets were resuspended in glutathione $S$-transferase column buffer $(50 \mathrm{mM}$ Tris- $\mathrm{HCl}, \mathrm{pH}$ 8.0, $250 \mathrm{mM} \mathrm{NaCl}, 1 \mathrm{mM}$ EDTA) and lysed by sonication. Lysate was clarified by centrifugation and applied to a GSTrap HP column (GE Biosciences). C3d was cleaved from the column by digesting with 50 units of thrombin overnight at $4^{\circ} \mathrm{C}$ and subsequently purified by size-exclusion chromatography. The purity of C3d was verified using SDS-PAGE. A second form of recombinant human C3d encompassing the same region was also produced as previously described (40). Binding of the antibodies to this construct by ELISA was performed to ensure that the antibodies bound a C3d epitope that was present on protein generated through independent methods.

Recombinant murine C3d. Murine C3d was cloned from murine cDNA using a forward primer containing a BamH I restriction site (5' CGC GGA TCC GCG GCT GTG GAC GGG GAG 3') and a reverse primer containing an EcoRI restriction site (5' CCG GAA TTC CGG TCA TCA ACG GCT GGG GAG GTG $3^{\prime}$ ). The amplified fragment was inserted into pGEX vector and generated by the same methods used for the human C3d. This recombinant murine $\mathrm{C} 3 \mathrm{~d}$ was used as a target antigen in ELISA binding studies.

Recombinant CR2 SCR1-2. Recombinant maltose-binding protein-tagged (MBP-tagged) CR2 SCR1-2 (MBP-CR2) comprising residues 1-133 of wild-type $\mathrm{CR} 2$ and encompassing the first $2 \mathrm{SCR}$ modules were expressed in E. coli as previously described (41-43). Briefly, MBP-CR2 SCR1-2-transformed colonies of E. coli BL21 were expanded to 4 liters in LB media and grown at $37^{\circ} \mathrm{C}$ until an $A_{600}$ of 0.3 was obtained. Cultures were then induced with $0.3 \mathrm{mM} \mathrm{IPTG}$ at $20^{\circ} \mathrm{C}$ overnight before harvesting by centrifugation. Resulting cell pellets were resuspended in a column buffer containing $20 \mathrm{mM}$ Tris- $\mathrm{HCl}$ ( $\mathrm{pH}$ 7.4), $0.2 \mathrm{M} \mathrm{NaCl}$, and $1 \mathrm{mM}$ EDTA prior to lysis by sonication. The resulting lysate was clarified by centrifugation and recombinant MBP-CR2, which was initially purified by successive amylose-affinity and size-exclusion chromatographic steps. Finally, the 

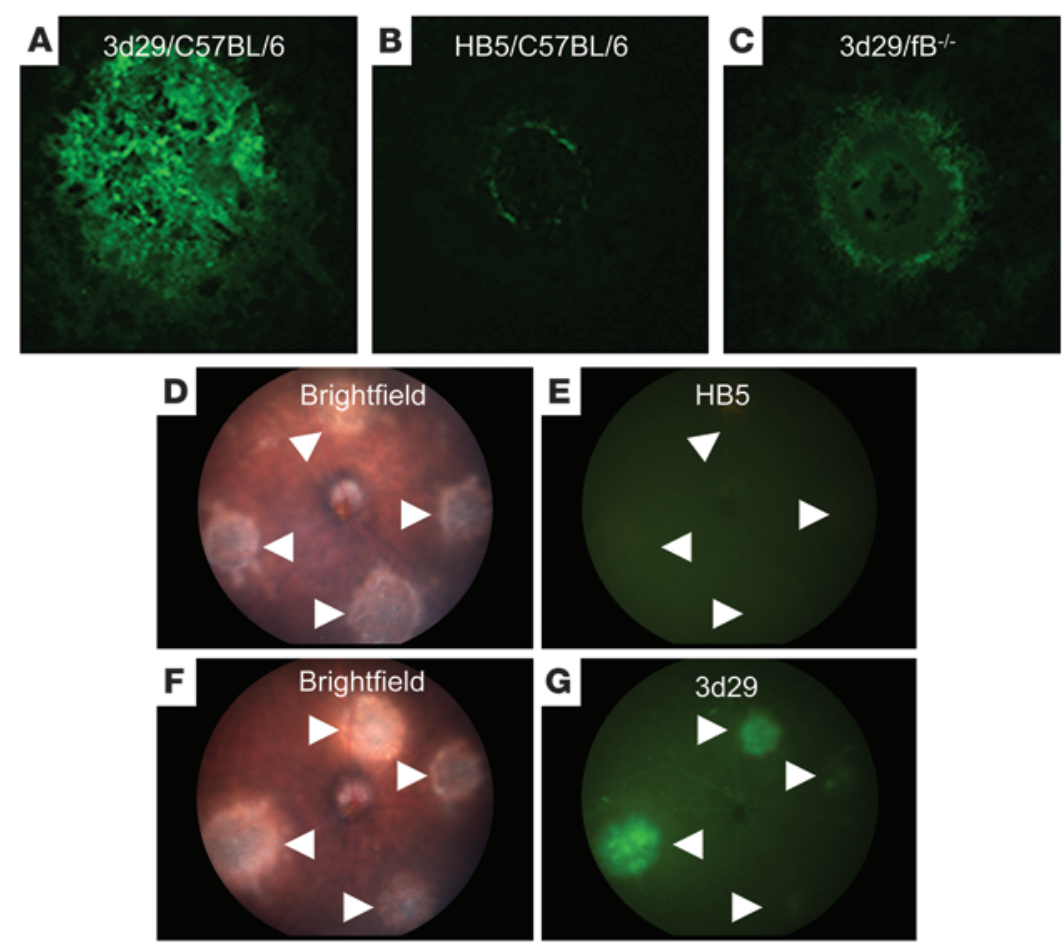

\section{Figure 10}

Clones 3d29 target tissue-bound C3 fragments in the retina in a model of CNV. Four laser spots in each eye were created by Argon laser photocoagulation. (A) FITC-3d29 strongly bound to CNV lesions in flat mounts made from wild-type mice. (B) Low-intensity staining was observed for HB5, a control antibody, to the edge of the CNV lesions in flat mounts made from wild-type mice. (C) Low-intensity staining of FITC-3d29 was observed in CNV lesions in flat mounts made from $f B^{-1-}$ mice. (D) Bright-field image revealing 4 depigmented CNV lesions in a wild-type mouse. E) Fluorescence image of the same fundus demonstrating that no fluorescence is detectable in live CNV mice injected with $0.2 \mathrm{mg}$ FITC-HB5. (F) Bright-field image revealing 4 depigmented CNV lesions in a wild-type mouse injected with FITC-3d29. (G) Fluorescence image of the same fundus demonstrating that fluorescence is clearly detectable in live CNV mice injected with $0.2 \mathrm{mg}$ FITC-3d29. Original magnification, $\times 630$ for $\mathbf{A}-\mathbf{C}$ and resolution element ("resel") of approximately $4 \mu \mathrm{m}$ for D-E. recombinant MBP-CR2 was applied to a C3d-affinity column generated by binding GST-tagged C3d to a GSTrap column (GE Biosciences) and eluted with a linear $\mathrm{NaCl}$ gradient. The resulting protein was then concentrated, buffer-exchanged into PBS $\left(1.6 \mathrm{mM} \mathrm{MgCl}_{2}, 0.9 \mathrm{mM} \mathrm{KCl}\right.$, $\left.0.5 \mathrm{mM} \mathrm{KH}_{2} \mathrm{PO}_{4}, 45.6 \mathrm{mM} \mathrm{NaCl}, 2.7 \mathrm{mM} \mathrm{Na}_{2} \mathrm{HPO}_{4}, \mathrm{pH} 7.4\right)$, and its purity tested by SDS-PAGE.

Purified complement proteins. Binding studies were also performed using commercially available purified complement proteins (C3, C3b, iC3b, and C3d; all from CompTech).

\section{Mice and animal models}

To generate monoclonal antibodies against $\mathrm{C} 3 \mathrm{~d}$, mice with a targeted deletion of the $\mathrm{C} 3$ gene were immunized with recombinant human C3d. These mice were generated as previously described (19). C57BL/ 6 wild-type mice were used for some in vivo experiments, and serum was collected from these mice for in vitro assays that required murine complement proteins. Mice with targeted deletion of the gene for factor $\mathrm{H}$ were generated as previously described (29). Kidney sections from these mice were used to test binding of the anti-C $3 \mathrm{~d}$ antibodies to tissue-bound $\mathrm{C} 3$ fragments in vitro, and $\mathrm{fH}^{-/-}$mice were injected with purified anti-C3d antibodies to test binding of the antibodies to tissue-bound C3 fragments in vivo. Kidney sections from mice that have targeted deletion of the gene for factor I, and thus do not generate iC $3 \mathrm{~b}$, were used to test whether the antibodies bind to the $\mathrm{C} 3 \mathrm{~b}$ fragment (44). Mice with targeted deletion of the gene for complement factor $\mathrm{B}$ gene were used as a negative control for binding of the FITC-labeled anti-C3d antibodies against CNV lesions (45).

To induce CNV lesions, 3-month-old mice were anesthetized (xylazine and ketamine, 20 and $80 \mathrm{mg} / \mathrm{kg}$, respectively) and their pupils were dilated (2.5\% phenylephrine $\mathrm{HCl}$ and $1 \%$ atropine sulfate). Argon laser photocoagulation $(532 \mathrm{~nm}, 100 \mu \mathrm{m}$ spot size, 0.1-second duration, $100 \mathrm{~mW}$ ) was used to generate 4 laser spots in each eye surrounding the optic nerve, using a hand-held coverslip as a contact lens (11). For tail vein injections, the vein was vasodilated by heat, a $25-\mathrm{G}$ needle was inserted, and a volume of $100 \mu \mathrm{l}$ was injected. The dosing and treatment schedule is outlined in the Results section.

\section{Immunization protocol and hybridoma generation}

The humoral immune response to the immunizations was assessed by ELISA using C3d as the target. The mice developed high titers of anti-C3d antibodies after 3 injections of 60 to $100 \mu \mathrm{g}$ of protein (the first injection using complete Freund's adjuvant and the second and third injections using incomplete Freund's adjuvant). The mice were then injected intraperitoneally with $100 \mu \mathrm{g}$ of C3d, and after 72 hours the spleen was harvested for fusion to Sp2/0 hybridoma cells (46). To prevent exposure of the anti-C3d hybridomas to $\mathrm{C} 3 \mathrm{~d}$ during the cloning process, the cells were grown in serum-free media supplemented with hypoxanthine-aminopterin-thymidine (HAT) (Sigma-Aldrich), and peritoneal macrophages from $\mathrm{C}^{-1-}$ mice were used as the feeder cells during this process. Single-cell clones were generated and specificity of the clones to C3d was confirmed by ELISA, as described below.

\section{ELISAs}

C3d ELISAs. To assess the reactivity of antibodies against C3d, ELISAs were performed using purified forms of C3 activation fragments from several different sources (see Reagents section above). Direct ELISAs were performed by affixing 30-50 ng of the $\mathrm{C} 3$ fragment to the ELISA plate overnight at $4^{\circ} \mathrm{C}$ and $\mathrm{pH}$ 7.4. The plates were blocked with $1 \%$ BSA in PBS for 2 hours at room temperature. Antibody was added to the wells at $5 \mu \mathrm{g} / \mathrm{ml}$, incubated, and the plates were washed 4 times. Bound antibodies were then detected with HRP-conjugated anti-mouse IgG (MP Biomedicals). Sandwich ELISAs were performed by incubating polyclonal anti-human C3d antibody (Dako) to the ELISA plates in order to capture the C3d. Binding of the antibodies to the captured C3d was then detected as above.

C3d-CR2/anti-C3d monoclonal antibody competition assay. Plates were incubated overnight at $4{ }^{\circ} \mathrm{C}$ with wild-type C3d at a concentration of $5 \mu \mathrm{g} / \mathrm{ml}$ in a $50 \mathrm{mM}$ sodium bicarbonate buffer ( $\mathrm{pH}$ 8.8). After coating, plates were 
blocked using 1\% BSA in PBS (pH 7.4), for 1 hour at room temperature. Plates were then washed 3 times using PBS-Tween 20 (0.05\%). Recombinant wild-type MBP-CR2 $(10 \mu \mathrm{g} / \mathrm{ml})$ was added to half of the C3d-coated wells to act as a positive control. To the other half of the C3d-coated wells, we added $10 \mu \mathrm{g} / \mathrm{ml}$ of recombinant wild-type MBP-CR2 containing 1 of the following anti-C3d monoclonal antibodies: 3d8B; 3d31; 3d15; 3d9a; $3 \mathrm{~d} 11 ; 3 \mathrm{~d} 16 ; 3 \mathrm{~d} 10 ; 3 \mathrm{~d} 3$; or $3 \mathrm{~d} 29$ at concentrations ranging from 1.625 to $26 \mu \mathrm{g} / \mathrm{ml}$ in PBS. After a 1-hour incubation period, the plates were washed and then incubated with commercially available HRP-conjugated antiMBP antibody (New England BioLabs). After a further 1-hour incubation period, binding of MBP-CR2 to the plate-bound C3d was detected with 2,2'-azinobis(3-ethylbenzthiazoline-6-sulfonic acid) (ABTS).

\section{Western blot analysis and pull-down studies}

Western blot analysis was performed by resolving $1 \mu \mathrm{g}$ of purified complement protein on a $10 \%$ Bis-Tris polyacrylamide gel (Invitrogen) under denaturing conditions. The protein was then transferred to a nitrocellulose membrane. C3 fragments were then detected by incubating the membrane with $25 \mu \mathrm{g}$ of each antibody $(0.5 \mathrm{mg} / \mathrm{ml})$ for 1 hour at room temperature, and bound antibody was detected with HRP-conjugated anti-mouse IgG.

Immunoprecipitation of complement fragments was performed by adding $100 \mu \mathrm{g}$ of antibody to $75 \mu \mathrm{l}$ of protein G sepharose (GE Healthcare) preblocked with $1 \%$ BSA for 1 hour. The antibodies were incubated with the protein $\mathrm{G}$ sepharose for 2 hours, excess antibody was removed by washing the sepharose with PBS, $150 \mu$ l of serum from RAG-1 knockout mice was added, and the mixture was incubated overnight at $4^{\circ} \mathrm{C}$. The protein $\mathrm{G}$ sepharose was then washed 3 times in PBS, resuspended in loading buffer, and separated by SDS-PAGE. The isolated C 3 fragments were detected by Western blot analysis using $\mathrm{mAb} 3 \mathrm{~d} 11$.

\section{Measurement of antibody affinities by surface plasmon resonance}

The binding of clones $3 \mathrm{~d} 8 \mathrm{~b}, 3 \mathrm{~d} 9 \mathrm{a}$, and $3 \mathrm{~d} 29$ to recombinant human C3d was examined using a BIAcore 3000 (Biacore) at the University of Colorado Biophysics Core. C3d was immobilized on a carboxymethyl-dextran (CM5) chip using random amine coupling with 1-ethyl-3-[3-dimethylaminopropyl]carbodiimide hydrochloride/N-hydroxysulfosuccinimide as the activating reagent. Recombinant human C3d was immobilized at a concentration of $50 \mu \mathrm{g} / \mathrm{ml}$ in $100 \mathrm{mM}$ sodium acetate, $\mathrm{pH}$ 5.0. The remaining activated groups on the surface of the chip were blocked with a 1-M ethanolamine solution ( $\mathrm{pH} 8.5)$. Experiments were conducted in $10 \mathrm{mM}$ HEPES, $150 \mathrm{mM} \mathrm{NaCl}$, and $0.005 \%$ P20 (pH 7.4), and the chip was regenerated between runs with two $10-\mu \mathrm{l}$ injections of $10 \mathrm{mM} \mathrm{NaOH}$. Each antibody was injected at concentrations of 90, 30, and $10 \mathrm{nM}$ for 1 minute at a flow rate of $50 \mu \mathrm{l}$ per minute, and dissociation of the resulting antibody-C3d complexes was monitored for 10 minutes. All injections were performed in triplicate to verify reproducibility and all data were double referenced using a blank flow cell and a blank injection of buffer to account for nonspecific binding and baseline drift, respectively. Data were fit using a 1:1 Langmuir binding model and data analysis was performed using SCRUBBER-2 software (distributed by David Myszka of the University of Utah Center for Biomolecular Interactions).

\section{Complement assays}

Zymosan activation assay. Zymosan particles were opsonized with murine $\mathrm{C} 3$ fragments by incubating the particles with complement-sufficient mouse serum as previously described (27). The particles were washed and then incubated with $2 \mu \mathrm{g}$ of purified anti-C3d antibody, and bound antibody was detected with FITC-conjugated anti-mouse IgG (MP Biotech). The samples were analyzed by flow cytometry and compared with a positive control (C3 deposition detected with a polyclonal anti-mouse C3; MP
Biomedicals) or with a negative control (no serum added). In some experiments, biotinylated antibodies were incubated with the particles in the presence of the activated serum, or fresh mouse serum was added to the particles at the incubation step. Bound antibody was then detected with streptavidin-FITC in order to test whether $\mathrm{C} 3$ and $\mathrm{C} 3$ fragments in the serum would compete with C3 on the zymosan surface for the antibody.

Alternative pathway bemolytic assay. This assay was performed as previously described (27). Briefly, rabbit erythrocytes (Colorado Serum Company) were washed and then resuspended in a solution of $1.1 \% \mathrm{NaCl}, 0.0025 \%$ Na-5,5 diethyl barbiturate ( $\mathrm{pH}$ 7.35), 8 mM EGTA, and $2 \mathrm{mM} \mathrm{MgCl}_{2}$ (GVB/ $\mathrm{Mg} / \mathrm{EGTA}$ ). Fifty microliters of this suspension was added to human serum $(5-100 \mu \mathrm{l})$, and buffer solution was added to bring the final volume up to $150 \mu$ l. Erythrocytes in buffer without serum were used as a negative control, and erythrocytes added to $100 \mu \mathrm{l}$ of distilled water were used as a positive control (complete lysis). Samples were incubated at $37^{\circ} \mathrm{C}$ for 30 minutes, with occasional shaking to keep the cells in suspension. The reactions were stopped by adding $1.5 \mathrm{ml}$ of cold PBS and the samples were spun at $1,000 \mathrm{~g}$ for 5 minutes. The optical density of each supernatant was read at $415 \mathrm{~nm}$ using a spectrophotometer (Bio-Rad). We determined the concentration of serum that caused approximately $50 \%$ lysis of the erythrocytes. The reactions were then repeated with the addition of 0 to $40 \mu \mathrm{g}$ of each antibody. The percent lysis for each reaction was compared with serum alone, and the change in lysis was reported as a percentage.

Buffers. DGVB ${ }^{2+}$ buffer: $1 \mathrm{mM} \mathrm{MgCl} 2,0.15 \mathrm{mM} \mathrm{CaCl}_{2}, 71 \mathrm{mM}$ $\mathrm{NaCl}, 0.1 \%(\mathrm{w} / \mathrm{v})$ gelatin, $2.5 \%(\mathrm{w} / \mathrm{v})$ dextrose, and $2.47 \mathrm{mM}$ sodium 5',5"-diethyl barbiturate ( $\mathrm{pH} 7.35$ ); $\mathrm{Mg}^{2+}$ EGTA buffer: $10 \mathrm{mM} \mathrm{Na} 2$ EGTA, $7 \mathrm{mM} \mathrm{MgCl}_{2}, 59 \mathrm{mM} \mathrm{NaCl}, 0.083 \%$ (w/v) gelatin, $2.075 \%$ (w/v) dextrose, and $2.05 \mathrm{mM}$ sodium $5^{\prime}, 5^{\prime \prime}$-diethyl barbiturate ( $\left.\mathrm{pH} 7.3-7.6\right) ; 10 \mathrm{mM}$ EDTA buffer: $10 \mathrm{mM} \mathrm{Na}_{2}$ EDTA, $128 \mathrm{mM} \mathrm{NaCl}, 0.1 \%$ (w/v) gelatin, and $4.45 \mathrm{mM}$ sodium $5^{\prime}, 5^{\prime \prime}$-diethyl barbiturate ( $\mathrm{pH} 7.35$ ); $40 \mathrm{mM}$ EDTA buffer: $40 \mathrm{mM} \mathrm{Na}_{2}$ EDTA, $85 \mathrm{mM} \mathrm{NaCl}, 0.1 \%$ (w/v) gelatin, and $2.96 \mathrm{mM}$ sodium $5^{\prime}, 5^{\prime \prime}$-diethyl barbiturate ( $\left.\mathrm{pH} 7.35\right)$.

Preparation of cell-bound C3b. Ab-sensitized sheep erythrocytes (EA cells, $5 \mathrm{ml}, 5 \times 10^{8} / \mathrm{ml}$ ) obtained from CompTech were washed twice and resuspended in $5 \mathrm{ml}$ of $\mathrm{DGVB}^{2+}$ buffer, mixed with $37.5 \mu \mathrm{g}$ of human $\mathrm{C} 1$ in $5 \mathrm{ml}$ of $\mathrm{DGVB}^{2+}$, and incubated for 15 minutes at $30^{\circ} \mathrm{C}$. The resulting cells (EAC1) were washed twice and resuspended in $5 \mathrm{ml}$ of $\mathrm{DGVB}^{2+}$, mixed with $50 \mu \mathrm{g}$ of human $\mathrm{C} 4$ suspended in $5 \mathrm{ml}$ of $\mathrm{DGVB}^{2+}$, and incubated for 15 minutes at $30^{\circ} \mathrm{C}$. These cells (EAC1, 4) were washed twice and suspended in $5 \mathrm{ml}$ of $\mathrm{DGVB}^{2+}$, mixed with $250 \mu \mathrm{g}$ of human $\mathrm{C} 3$ and $5 \mu \mathrm{g}$ of human $\mathrm{C} 2$ suspended in $5 \mathrm{ml}$ of $\mathrm{DGVB}^{2+}$, and incubated for 30 minutes at $30^{\circ} \mathrm{C}$. The resulting cells (EAC1, 4, 2, 3) were washed and resuspended in $5 \mathrm{ml}$ of $10 \mathrm{mM}$ EDTA buffer and incubated at $37^{\circ} \mathrm{C}$ for 2 hours to allow for dissociation of the active classical pathway convertases. The resulting C3bcoated cells were washed twice in $5 \mathrm{ml} 10 \mathrm{mM}$ EDTA buffer, twice in $5 \mathrm{ml}$ of $10 \mathrm{mM} \mathrm{Mg}^{2+}$ EGTA buffer, and resuspended in $10 \mathrm{mM} \mathrm{Mg}^{2+}$ EGTA buffer to a final concentration of $1 \times 10^{8}$ per milliliter. They were stored at $4^{\circ} \mathrm{C}$ and used within 1 week.

Effects of anti-C3 mAbs on the activity of cell-bound C3bBbP complexes. C3bcoated sheep erythrocytes were prepared as described $(47,48)$. C3b-coated sheep erythrocytes $(100 \mu \mathrm{l}), 50 \mu \mathrm{l}$ of purified factor D ( $5 \mathrm{ng}$ in $\mathrm{Mg}^{2+}$ EGTA buffer), $50 \mu \mathrm{l}$ of properdin (45 $\mathrm{ng}$ in $\mathrm{Mg}^{2+}$ EGTA buffer), and $50 \mu \mathrm{l}$ of factor B (3-5 ng in $\mathrm{Mg}^{2+}$ EGTA buffer) were mixed together and incubated at $30^{\circ} \mathrm{C}$ for 30 minutes. In some cases, the factor B was replaced by $50 \mu \mathrm{l}$ of $\mathrm{Mg}^{2+}$ EGTA buffer. Samples were chilled to $4^{\circ} \mathrm{C}$ and treated with $150 \mu \mathrm{l}$ $40 \mathrm{mM}$ EDTA buffer (40 mM Na 2 EDTA, $85 \mathrm{mM} \mathrm{NaCl}, 0.1 \%$ [w/v] gelatin, and $2.96 \mathrm{mM}$ sodium $5^{\prime}, 5^{\prime \prime}$-diethyl barbiturate, $\mathrm{pH} 7.35$ ), containing in some cases $1 \mu \mathrm{g}$ of mouse anti-human C $3 \mathrm{~d} \mathrm{mAb}$. Samples were then incubated for 0 to 3 hours at $30^{\circ} \mathrm{C}$ to permit spontaneous C3bBbP dissociation. In some cases, this incubation was undertaken with or without 
$400 \mu \mathrm{g}$ of factor $\mathrm{H}$ for 30 minutes to assess factor $\mathrm{H}$-dependent convertase decay acceleration. Functional convertases were then quantified by adding $150 \mu \mathrm{l}$ of a 1:20 dilution of guinea pig serum (Colorado Serum) in $40 \mathrm{mM}$ EDTA buffer to all samples, followed by incubation at $37^{\circ} \mathrm{C}$ for 60 minutes. Additional samples included cell lysis controls in which cells were treated with $450 \mu \mathrm{l}$ of distilled water alone and a negative control in which cells were treated with $450 \mu \mathrm{l}$ of $\mathrm{DGVB}^{2+}$ buffer alone. All samples were then centrifuged and the $\mathrm{OD}_{414}$ of the supernatants was determined. Hemolytic activity levels were expressed as $Z$ values, the average number of lytic sites or MAC pores formed per red blood cell, and were calculated using the expression: $Z=-\ln (1-y)$, where $y$ is the proportion of lysed cells. Each determination was the average of duplicate points. All complement proteins were of human origin and were purchased from CompTech.

\section{Immunofluorescence microscopy}

For immunofluorescence microscopy, sagittal sections of the kidneys were snap-frozen in OCT compound (Sakura Finetek USA). Five-micrometer sections were cut with a cryostat and stored at $-80^{\circ} \mathrm{C}$ until used. The slides were later fixed with acetone and stained with antibody against mouse $\mathrm{C} 3$ or mouse IgG. The slides were then counterstained with hematoxylin (Vector Laboratories) and viewed using an Olympus BX51 microscope. The antiC3d antibodies were used at a concentration of $2 \mu \mathrm{g} / \mathrm{ml}$ for tissue staining.

For immunofluorescence microscopy of RPE/choroid, flat-mount preparations were incubated with FITC-labeled antibodies. In brief, eyes were collected and immersion fixed in $4 \%$ paraformaldehyde for 30 minutes at $4^{\circ} \mathrm{C}$ after which the anterior chamber, lens, and retina were removed. The eyecups were incubated in blocking solution (3\% BSA, $10 \%$ normal goat serum, and $0.4 \%$ Triton- $X$ in tris-buffered saline) for 1 hour followed by anti-C3d antibodies (1:100 of $1 \mathrm{mg} / \mathrm{ml}$ solution) overnight at $4^{\circ} \mathrm{C}$ in blocking solution. Following extensive washing, eyecups were flattened using 4 relaxing cuts, coverslips were applied with Fluoromount (Southern Biotechnology Associates), and slides were examined by confocal microscopy (Leica TCS SP2 AOBS; Leica).

\section{Fundus imaging}

Fundus imaging was performed using the Micron III retinal imaging microscope (Phoenix Research Laboratories), which is based on a custom optical system with a 300-W xenon light source and a 3-chip CCD camera, operating at 30 frames per second in linear/diagnostic mode. For imaging, mice were anesthetized, their pupils were dilated as described above and secured in the imaging cradle. Optical contact between the cornea of the mouse and the lens of the optical system was established through a drop of methylcellulose. A fundus photograph was obtained using bright-field imaging to focus on the $\mathrm{CNV}$ lesions, after which the mode was switched to FITC fluorescence imaging (excitation at $490 \mathrm{~nm}$ ). JPEG images were exported to Adobe Photoshop to assemble the photos and to extract images of individual lesions. Images obtained with this system have a resolution element of approximately $4 \mu \mathrm{m}$. To improve visualization of individual lesions, contrast enhancement using identical parameters for control and experimental images was applied.

\section{Statistics}

Data were analyzed using GraphPad Prism software (GraphPad) and the results for groups are presented as the mean \pm SEM. Comparison between groups was performed using unpaired 2-tailed $t$ tests. A $P$ value of less than 0.05 was considered significant.

\section{Study approval}

The mice were housed and maintained in the University of Colorado Center for Laboratory Animal Care in accordance with the NIH Guidelines for the Care and Use of Laboratory Animals. The CNV model procedures and fundus imaging were performed in accordance with the ARVO Statement for the Use of Animals in Ophthalmic and Vision Research and were approved by the IACUC of the Medical University of South Carolina. All other animal experiments and procedures were approved by the IACUC of the University of Colorado.

\section{Acknowledgments}

We thank Shaun Bevers at the University of Colorado Biophysics Core for technical assistance. This work was supported in part by the Beckman Initiative for Macular Research (to V.M. Holers), the KIDNEEDS Foundation (to J.M. Thurman), NIH grants R01 AR51749 (to V.M. Holers), R01 DK076690 (to J.M. Thurman), and R01 AI051436 (to D.E. Hourcade), and a sponsored research agreement with Alexion Pharmaceuticals, Inc.

Received for publication July 18, 2012, and accepted in revised form February 21, 2013.

Address correspondence to: Joshua M. Thurman, Division of Nephrology and Hypertension, B-115, University of Colorado Denver School of Medicine, P.O. Box 6511, Aurora, Colorado 80045, USA. Phone: 303.724.7584; Fax: 303.724.7581; E-mail: Joshua.Thurman@ucdenver.edu.
1. Ricklin D, Hajishengallis G, Yang K, Lambris JD. Complement: a key system for immune surveillance and homeostasis. Nat Immunol. 2010;11(9):785-797.

2. Walport MJ. Complement. Second of two parts. N Engl J Med. 2001;344:1140-1144.

3. Law SK, Dodds AW. The internal thioester and the covalent binding properties of the complement proteins C3 and C4. Protein Sci. 1997;6(2):263-274.

4. Sahu A, Kozel TR, Pangburn MK. Specificity of the thioester-containing reactive site of human $\mathrm{C} 3$ and its significance to complement activation. Biochem J. 1994;2:429-436.

5. Sahu A, Pangburn MK. Covalent attachment of human complement C3 to IgG. Identification of the amino acid residue involved in ester linkage formation. J Biol Chem. 1994;269(46):28997-29002.

6. Schulze M, Pruchno CJ, Burns M, Baker PJ, Johnson RJ, Couser WG. Glomerular C3c localization indicates ongoing immune deposit formation and complement activation in experimental glomerulonephritis. Am J Pathol. 1993;142(1):179-187.

7. Hageman GS, Luthert PJ, Victor Chong NH, Johnson
LV, Anderson DH, Mullins RF. An integrated hypothesis that considers drusen as biomarkers of immunemediated processes at the RPE-Bruch's membrane interface in aging and age-related macular degeneration. Prog Retin Eye Res. 2001;20(6):705-732.

8 . Atkinson C, et al. Targeted complement inhibition by $\mathrm{C} 3 \mathrm{~d}$ recognition ameliorates tissue injury without apparent increase in susceptibility to infection. J Clin Invest. 2005;115(9):2444-2453.

9. Serkova NJ, et al. Renal inflammation: targeted iron oxide nanoparticles for molecular MR imaging in mice. Radiology. 2010;255(2):517-526.

10. Sargsyan SA, et al. Detection of glomerular complement C3 fragments by magnetic resonance imaging in murine lupus nephritis. Kidney Int. 2012; 81(2):152-159.

11. Rohrer B, et al. A targeted inhibitor of the alternative complement pathway reduces angiogenesis in a mouse model of age-related macular degeneration. Invest Ophthalmol Vis Sci. 2009;50(7):3056-3064.

12. Rohrer B, Coughlin B, Bandyopadhyay M, Holers VM. Systemic human CR2-targeted complement alternative pathway inhibitor ameliorates mouse laser-induced choroidal neovascularization. J Ocul Pharmacol Ther. 2012;28(4):402-409.

13. Webb S. Pharma interest surges in antibody drug conjugates. Nat Biotechnol. 2011;29(4):297-298.

14. Guthridge JM, et al. Structural studies in solution of the recombinant $\mathrm{N}$-terminal pair of short consensus/complement repeat domains of complement receptor type 2 (CR2/CD21) and interactions with its ligand C3dg. Biochemistry. 2001; 40(20):5931-5941.

15. Isenman DE, Leung E, Mackay JD, Bagby S, van den Elsen JM. Mutational analyses reveal that the staphylococcal immune evasion molecule Sbi and complement receptor 2 (CR2) share overlapping contact residues on $\mathrm{C} 3 \mathrm{~d}$ : implications for the controversy regarding the CR2/C3d cocrystal structure. Jimmunol. 2010;184(4):1946-1955.

16. Dempsey PW, Allison ME, Akkaraju S, Goodnow CC, Fearon DT. C3d of complement as a molecular adjuvant: bridging innate and acquired immunity. Science. 1996;271(5247):348-350. 
17. Janssen BJ, Christodoulidou A, McCarthy A, Lambris JD, Gros P. Structure of C3b reveals conformational changes that underlie complement activity. Nature. 2006;444(7116):213-216.

18. Shaw CD, et al. Delineation of the complement receptor type 2-C3d complex by site-directed mutagenesis and molecular docking. J Mol Biol. 2010; 404(4):697-710.

19. Wessels MR, Butko P, Ma M, Warren HB, Lage AL, Carroll MC. Studies of group B streptococcal infection in mice deficient in complement component $\mathrm{C} 3$ or $\mathrm{C} 4$ demonstrate an essential role for complement in both innate and acquired immunity. Proc Natl Acad Sci U S A. 1995;92(25):11490-11494.

20. Li Y, Williams ME, Cousar JB, Pawluczkowycz AW, Lindorfer MA, Taylor RP. Rituximab-CD20 complexes are shaved from Z138 mantle cell lymphoma cells in intravenous and subcutaneous SCID mouse models. J Immunol. 2007;179(6):4263-4271.

21. Strunk RC, Kunke KS, Giclas PC. Human peripheral blood monocyte-derived macrophages produce haemolytically active $\mathrm{C} 3$ in vitro. Immunology. 1983;49(1):169-174.

22. Daha MR, Fearon DT, Austen KF. C3 nephritic factor $(\mathrm{C} 3 \mathrm{NeF})$ : stabilization of fluid phase and cellbound alternative pathway convertase. J Immunol. 1976;116(1):1-7.

23. Weiler JM, Daha MR, Austen KF, Fearon DT. Control of the amplification convertase of complement by the plasma protein beta1H. Proc Natl Acad Sci US A. 1976;73(9):3268-3272.

24. Pangburn MK, Schreiber RD, Muller-Eberhard HJ. Human complement C3b inactivator: isolation, characterization, and demonstration of an absolute requirement for the serum protein beta1 $\mathrm{H}$ for cleavage of C3b and C4b in solution. J Exp Med. 1977; 146(1):257-270.

25. Wu J, Wu YQ, Ricklin D, Janssen BJ, Lambris JD, Gros P. Structure of complement fragment C3b-factor $\mathrm{H}$ and implications for host protection by complement regulators. Nat Immunol. 2009;10(7):728-733.

26. Lyubchenko T, dal Porto J, Cambier JC, Holers VM. Coligation of the B cell receptor with complement receptor type $2(\mathrm{CR} 2 / \mathrm{CD} 21)$ using its natu- ral ligand C3dg: activation without engagement of an inhibitory signaling pathway. J Immunol. 2005; 174(6):3264-3272.

27. Thurman JM, et al. A novel inhibitor of the alternative complement pathway prevents antiphospholipid antibody-induced pregnancy loss in mice. Mol Immunol. 2005;42(1):87-97.

28. Paixao-Cavalcante D, Hanson S, Botto M, Cook HT, Pickering MC. Factor $\mathrm{H}$ facilitates the clearance of GBM bound iC3b by controlling C3 activation in fluid phase. Mol Immunol. 2009;46(10):1942-1950.

29. Pickering MC, et al. Uncontrolled C3 activation causes membranoproliferative glomerulonephritis in mice deficient in complement factor H. Nat Genet. 2002;31(4):424-428.

30. Thurman JM, Ljubanovic D, Edelstein CL, Gilkeson GS, Holers VM. Lack of a functional alternative complement pathway ameliorates ischemic acute renal failure in mice. J Immunol. 2003;170(3):1517-1523.

31. Renner B, et al. Binding of factor $\mathrm{H}$ to tubular epithelial cells limits interstitial complement activation in ischemic injury. Kidney Int. 2011;80(2):165-173.

32. Nozaki M, et al. Drusen complement components $\mathrm{C} 3 \mathrm{a}$ and C5a promote choroidal neovascularization. Proc Natl Acad Sci US A. 2006;103(7):2328-2333.

33. Leveziel N, et al. Genetic factors associated with age-related macular degeneration. Ophthalmologica. 2011;226(3):87-102.

34. van den Elsen JM, Isenman DE. A crystal structure of the complex between human complement receptor 2 and its ligand C3d. Science. 2011;332(6029):608-611.

35. Sekine $\mathrm{H}$, et al. The benefit of targeted and selective inhibition of the alternative complement pathway for modulating autoimmunity and renal disease in MRL/ lpr mice. Arthritis Rheum. 2011;63(4):1076-1085.

36. Song H, He C, Knaak C, Guthridge JM, Holers VM, Tomlinson S. Complement receptor 2-mediated targeting of complement inhibitors to sites of complement activation. J Clin Invest. 2003; 111(12):1875-1885

37. Sargsyan SA, Thurman JM. Molecular imaging of autoimmune diseases and inflammation. Mol Imaging. 2012;11(3):251-264.

38. Rother RP, Rollins SA, Mojcik CF, Brodsky RA, Bell
L. Discovery and development of the complement inhibitor eculizumab for the treatment of paroxysmal nocturnal hemoglobinuria. Nat Biotechnol. 2007;25(11):1256-1264

39. Li K, et al. Solution structure of the complex formed between human complement C3d and fulllength complement receptor type 2.J Mol Biol. 2008; 384(1):137-150

40. Kulik L, et al. Intrinsic B cell hypo-responsiveness in mice prematurely expressing human CR2/CD21 during B cell development. Eur J Immunol. 2007; 37(3):623-633.

41. Szakonyi G, et al. Structure of the Epstein-Barr virus major envelope glycoprotein. Nat Struct Mol Biol. 2006;13(11):996-1001.

42. Young KA, Chen XS, Holers VM, Hannan JP. Isolating the Epstein-Barr virus gp350/220 binding site on complement receptor type 2 (CR2/CD21). J Biol Chem. 2007;282(50):36614-36625.

43. Young KA, Herbert AP, Barlow PN, Holers VM, Hannan JP. Molecular basis of the interaction between complement receptor type 2 (CR2/CD21) and Epstein-Barr virus glycoprotein gp350. J Virol. 2008; 82(22):11217-11227.

44. Rose KL, et al. Factor I is required for the development of membranoproliferative glomerulonephritis in factor H-deficient mice. J Clin Invest. 2008; 118(2):608-618.

45. Matsumoto M, et al. Abrogation of the alternative complement pathway by targeted deletion of murine factor B. Proc Natl Acad Sci U S A. 1997; 94(16):8720-8725.

46. Kulik L, et al. Pathogenic natural antibodies recognizing annexin IV are required to develop intestinal ischemia-reperfusion injury. J Immunol. 2009; 182(9):5363-5373.

47. Hourcade DE, Wagner LM, Oglesby TJ. Analysis of the short consensus repeats of human complement factor B by site-directed mutagenesis. J Biol Chem. 1995;270(34):19716-19722.

48. Whaley K. Measurement of complement. In: Whaley K, ed. Methods in Complement for Clinical Immunologists. New York, New York, USA: Churchill Livingstone; 1985:77-139. 